Marquette University

e-Publications@Marquette

College of Communication Faculty Research and

Publications

Communication, College of

9-1-2010

\title{
Newspaper Theft, Self-Preservation and the Dimensions of Censorship
}

Erik Ugland

Marquette University, erik.ugland@mu.edu

Jennifer L. Lambe

University of Delaware

Accepted version. Communication Law and Policy, Vol. 15, No. 4 (September 2001), DOI. (C) 2010 Erik Ugland.

This is the author's version of the work. It is posted here by permission of Erik Ugland for personal use, not for redistribution. The definitive version was published in Communication Law and Policy, Volume 15 Issue 4, September 2010. doi:10.1080/10811680.2010.512509 (http://dx.doi.org/ $10.1080 / 10811680.2010 .512509)$ 


\title{
Newspaper Theft, Self-Preservation And The Dimensions of Censorship
}

\author{
Erik Ugland \\ Diederich College of Communication, Marquette University \\ Milwaukee, WI \\ Jingyu Bao \\ College of Communication, Marquette University \\ Milwaukee, WI \\ Jennifer L. Lambe \\ Department of Communication, University of Delaware \\ Newark, DE
}

One of the most common yet understudied means of suppressing free expression on college and university campuses is the theft of freelydistributed student publications, particularly newspapers. This study examines news accounts of nearly 300 newspaper theft incidents at colleges and universities between 1995 and 2008 in order to identify the manifestations and consequences of this peculiar form of censorship, and to augment existing research on censorship and tolerance by looking, not at what people say about free expression, but at what they do when they have the power of censorship in their own hands. Among the key findings is that men commit nearly $70 \%$ of newspaper thefts, which is inconsistent with much of the existing research on censorship and gender, and that those who censor college newspapers are far more concerned with their own self-preservation than with shaping public dialog on controversial social or political issues.

College and university campuses have always been regarded as quintessential public forums. They are, as the Supreme Court of the United States put it, "peculiarly the 'marketplace[s] of ideas. ${ }^{\prime \prime 1}$ Like all 
markets, however, they are occasionally distorted by both overt and subtle exertions of power. School officials sometimes seek to narrow the boundaries of acceptable discourse and to shield themselves from criticism, and individual communicators occasionally overreach in their attempts to amplify their own messages or to obscure those of others.

Student publications, which are the principal vehicles of communication on most campuses, are common targets of these restraints. Not only are they occasionally subjected to universityimposed punishments (prior review, adviser firings, funding withdrawals), they are also uniquely vulnerable to a more pedestrian but equally suppressive tactic: theft. Because nearly all student publications are disseminated freely on campuses via unattended distribution boxes, anyone with the temerity to gather them up and haul them away can effectively stifle the student press. Newspaper theft is a peculiar but not uncommon form of censorship. This study identified nearly 300 incidents of newspaper theft on college campuses between 1995 and 2008, in which more than 800,000 copies were stolen. ${ }^{2}$ This is no doubt just a fraction of the total thefts that occurred during this period, however, because these incidents often go unreported. ${ }^{3}$

No empirical research has been conducted on newspaper theft but it is an important research subject for at least two reasons. ${ }^{4}$ First, the theft of student publications is a significant educational, legal and public-policy problem. It imposes financial costs on the publications and their advertisers, ${ }^{5}$ it shuts off a prodigious channel of information and opinion, and it subverts the editorial discretion of student editors by giving the audience the equivalent of a heckler's veto. ${ }^{6}$ These problems are exacerbated by the fact that in most cases local laws and university policies do not explicitly authorize penalties for those who take material distributed free of charge. ${ }^{7}$ Even where there is a clear basis for punishment, school officials, campus police and local prosecutors often lack the will to pursue these cases. ${ }^{8}$ Indeed, some university officials have orchestrated the thefts themselves, ${ }^{9}$ and others have either refused to condemn them ${ }^{10}$ or dismissed them as a harmless form of counter-speech. ${ }^{11}$ 
The other key reason to study newspaper theft is that it provides a unique context in which to test and inform theories about political tolerance and the willingness to censor. There is a substantial, cross-disciplinary literature on censorship addressing everything from content triggers to demographic patterns to public attitudes. ${ }^{12}$ But those studies are almost always a step or two removed from people's actual experience and are instead built around survey hypotheticals. ${ }^{13}$ This study's focus, however, is not on what people say about free expression but on what they do when they have the power of censorship in their own hands. It also differs from some studies tracking incidents of censorship in that those who commit newspaper thefts typically expect, or hope, to remain anonymous - unlike many other censors whose acts are bounded by the legal and social scrutiny that attaches to their public behavior or official acts. ${ }^{14}$

Over the past seventy-five years, research on censorship and political tolerance has repeatedly shown a disparity between the public's attitudes about free expression generally and the willingness to support limitations in specific situations. ${ }^{15}$ Few studies, however, have explored the nexus or disjunction between people's expressions of intolerance (including their endorsement of censorship as a remedy) and their willingness to actually take affirmative steps themselves to prevent the dissemination of those ideas. This study seeks to provide some insight into those relationships - albeit somewhat indirectly ${ }^{16}$ while also examining the linkages between newspaper theft and the personal attributes of the thieves, particularly their gender. Finally, the study attempts to provide a portrait of newspaper theft as a social phenomenon by noting its frequency, the conditions under which it occurs, and the characteristics and motivations of those who engage in it. All of this will ideally provide some guidance for those fashioning legal and policy responses and for those seeking to build more broadly applicable theories of censorship and tolerance.

\section{Law and Policy Context}

Although the term "censorship" is typically used to describe the exercise of government power to limit public expression, ${ }^{17}$ private parties are also capable of suppressing others' speech. Both government and nongovernment actors can steal freely distributed

Communication Law and Policy, Vol. 15, No. 4 (September 2010): pg. 365-403. DOI. This article is (C) Taylor \& Francis (Routledge) and permission has been granted for this version to appear in e-Publications@Marquette. Taylor \& Francis (Routledge) does not grant permission for this article to be further copied/distributed or hosted elsewhere without the express permission from Taylor \& Francis (Routledge). 
newspapers, so a broader definition of censorship is more appropriate in this context - one that encompasses attempts by any party to shield another from content that the first party finds objectionable or that it assumes others will, or should, find objectionable. ${ }^{18}$ Using this definition, nearly all newspaper thefts are acts of censorship. ${ }^{19}$ Not all censorship raises constitutional problems, however. Because the First Amendment to the U.S. Constitution, as well as the free expression provisions of the various state constitutions, only limit the extent to which the government can restrict freedom of speech and press, newspaper thefts committed by private parties are not subject to any constitutional limitation. ${ }^{20}$ On the other hand, thefts committed or commissioned by the faculty, staff or administrators of public universities do trigger constitutional scrutiny, at least where the thieves are acting within the scope of their employment. ${ }^{21}$ In those cases, prior restraints of the press are only permissible when they are necessary to advance a government interest "of the highest order."22 Government censorship is perhaps an especially pernicious strain of suppression, and it warrants added attention, but the problems associated with newspaper theft are not limited to those instances in which a government actor is involved. A broader notion of censorship is therefore more useful in analyzing this particular tactic. Some might also contend that where university officials endorse or acquiesce to the theft of student publications, their actions are tantamount to censorship. Such cases fall outside of the definition used here, but certainly any ratification by university officials of censorship by others could have an inhibiting effect on future speech. So, those types of responses from school officials are highlighted here, but they are not treated as independent acts of censorship unless there was some active participation from school officials.

In those instances in which government actors are responsible for the theft of newspapers, there are First Amendment implications, although there is some ambiguity in this area of law. For example, most courts have held that public university officials cannot seize, censor or otherwise inhibit student media, even when those organizations bear the imprimatur of the university or receive its subsidy. ${ }^{23}$ But some courts have held that university officials have discretion to regulate speech that is tied to curricular activity ${ }^{24}$ or that occurs within a non-public forum. ${ }^{25}$ So, if a university has always 
played an active role as publisher by directly supervising a student media organization and exercising editorial control over its content, or if the organization operates as a faculty-directed, for-credit activity, some courts might be willing to afford university officials some editorial control. ${ }^{26}$

There is also at least a sliver of doubt regarding the constitutional standard that applies to school-sponsored expression on public university campuses. Nearly every court that has addressed this issue has concluded that university students ought to be afforded full First Amendment protection and that the applicable standard is the one adopted by the Supreme Court in Tinker v. Des Moines Independent Community School District, ${ }^{27}$ which held that public school officials can only restrict student speech that "materially disrupts classwork or [causes] substantial disorder or invasion of the rights of others." 28 One federal appellate court has complicated this area of law, however, by suggesting that student publications at public universities should be governed by the Supreme Court's ruling in Hazelwood $v$. Kuhlmeier, ${ }^{29}$ which held that public high school officials may censor school-sponsored publications as long as their actions are motivated by "legitimate pedagogical concerns." 30 In Hosty v. Carter, ${ }^{31}$ the United States Court of Appeals for the Seventh Circuit wrote that "Hazelwood provides [the] starting point" when evaluating the First Amendment rights of the staff of a school-sponsored university publication. ${ }^{32}$ The Hosty decision was widely criticized for drawing a bogus parallel between high school and college media, ${ }^{33}$ and certainly it represents the minority view among the courts, but it provides at least a plausible defense for university officials who suppress student publications.

Although federal and state constitutions provide a durable shield against newspaper thefts by public officials, the culprits in these cases are usually non-government actors. ${ }^{34} \mathrm{~A}$ more accessible remedy, therefore, might be criminal theft or larceny statutes. The language of these statutes, however, does not always clearly encompass the theft of material distributed for free, and most courts have not settled the question of when someone relinquishes control over material they intentionally leave unattended in a public place. ${ }^{35}$ As a result, some judges have thrown out criminal charges against newspaper thieves. ${ }^{36}$

Communication Law and Policy, Vol. 15, No. 4 (September 2010): pg. 365-403. DOI. This article is (C) Taylor \& Francis (Routledge) and permission has been granted for this version to appear in e-Publications@Marquette. Taylor \& Francis (Routledge) does not grant permission for this article to be further copied/distributed or hosted elsewhere without the express permission from Taylor \& Francis (Routledge). 
Even where a reasonable argument can be made that newspaper theft falls within the ambit of a criminal statute, police and prosecutors are often reluctant to pursue these cases in the absence of clear statutory language or court precedent. ${ }^{37}$ Three states - California, ${ }^{38}$ Colorado $^{39}$ and Maryland ${ }^{40}$ - have passed laws explicitly criminalizing the theft of freely distributed publications, and at least one municipality Berkeley, California ${ }^{41}$ - has done the same. But the law remains nebulous in most jurisdictions.

Although some people and organizations regard all newspaper thefts as criminal acts, ${ }^{42}$ university officials might be in a better position to address these issues than police or prosecutors. One way is by invoking university student conduct codes. These rarely address student publications specifically, but they provide a set of behavioral expectations and procedural mechanisms that can be used to hold newspaper thieves accountable and provide some recourse for the publications. Even more important might be the informal public statements that university officials make in response to these incidents. In 1993, then-University of Pennsylvania President Sheldon Hackney was excoriated for refusing to punish a group of students who stole 14,000 copies of the Daily Pennsylvanian to protest what they argued was racist content. Hackney responded equivocally to the theft by saying that "two important principles, diversity and free speech, seem to be in conflict." 43 This triggered a torrent of criticism from students, faculty and others who argued that Hackney had essentially legitimized newspaper theft as an appropriate means of rebuttal. ${ }^{44}$

The criticisms aimed at Hackney were built upon the assumption that university officials play an important role in shaping the behavior of members of their campus communities. If that is true, then it matters whether university officials regard newspaper thefts as innocuous college pranks or as serious affronts to the intellectual ethos of their campuses. And it matters how they respond, both procedurally and rhetorically. Indeed, there is a substantial body of research that suggests that tolerance and restraint are learned, ${ }^{45}$ so the educative role played by school officials should not be overlooked. An important aspect of this study, therefore, is to identify and evaluate the ways in which school officials - as well law enforcement officials and student journalists - have responded to newspaper theft incidents, how they

Communication Law and Policy, Vol. 15, No. 4 (September 2010): pg. 365-403. DOI. This article is (C) Taylor \& Francis (Routledge) and permission has been granted for this version to appear in e-Publications@Marquette. Taylor \& Francis (Routledge) does not grant permission for this article to be further copied/distributed or hosted elsewhere without the express permission from Taylor \& Francis (Routledge). 
have characterized the probity and legality of those acts and whether they have taken or proposed any corrective or punitive action.

\section{Literature Review: Censorship and Tolerance}

Research on censorship and tolerance includes work chronicling incidents of censorship in a variety of contexts, studies examining the content that inspires censorial acts, and explorations of the relationship between people's personal characteristics and their propensity to support government restraints targeting offensive or disfavored subjects or viewpoints. Collectively, these studies share a common aim of constructing theories to explain how political attitudes are formed and how they help predict support for formal restraints.

\section{Core Research and Conceptual Definitions}

Much of the research on censorship is tied to the broader concept of tolerance, which John L. Sullivan, James Piereson and George E. Marcus define as people's "willingness to permit the expression of ideas or interests one opposes." 46 This applies to both institutions and individuals whose levels of tolerance are usually measured by the extent to which they express opposition to speech "that challenge[s] [their] basic principles." ${ }^{17}$ In some studies, tolerance is presented as a set of attitudes, but other scholars emphasize actions. Sullivan, Piereson and Marcus, for example, contend that people who harbor prejudices about others are not necessarily intolerant. ${ }^{48}$ Prejudice becomes intolerance only when coupled with something external - either an act of suppression or some outward support for such acts. This is an important distinction because, as many authors have discovered, there is often an incongruity between people's self-reported tolerance of particular groups or ideas and their willingness to support or acquiesce to restrictions targeting those same groups or ideas. ${ }^{49}$ Conversely, people's declarations of intolerance do not always indicate a willingness to take or endorse restrictions. ${ }^{50}$ These disparities are partly a consequence of the methodological challenge of measuring beliefs, especially when the instruments used are disconnected, as survey questions necessarily are, from real-world decisional moments. Nevertheless, the attitude-action disparity is well documented. ${ }^{51}$ Of course, it is still useful to measure attitudes.

Communication Law and Policy, Vol. 15, No. 4 (September 2010): pg. 365-403. DOI. This article is (C) Taylor \& Francis (Routledge) and permission has been granted for this version to appear in e-Publications@Marquette. Taylor \& Francis (Routledge) does not grant permission for this article to be further copied/distributed or hosted elsewhere without the express permission from Taylor \& Francis (Routledge). 
Attitudes and behaviors are usually related, and attitudes (as reflected in public opinion) can serve as the foundation or justification for policy choices. ${ }^{52}$ But a full understanding of tolerance requires an examination of both actions and attitudes.

This study defines intolerance as an apprehension that the harms associated with particular speech are so great as to require some kind of restraint of that speech. Intolerance is simply disapproval combined with some move toward suppression. Most tolerance studies focus on people's core principles and identifying characteristics religion, ethnicity, ideology - rather than their ordinary beliefs or preferences. This is understandable in that researchers have operationalized the term in particular contexts, looking at special types of intolerance. Conceptually, however, this narrowing is harder to justify. Any disagreement with or disapproval of something - at least when coupled with action - can be considered intolerance, even though some forms of intolerance are certainly more consequential than others. Tolerance is often presented as both a value and a function, so it tends to appear in discussions and research focused on rights, democracy, pluralism and similar issues. ${ }^{53}$ But as a function, it can manifest itself in ways that are both profound and pedestrian, all with the same effect, so it is important to consider the gradations. In seeking to understand what leads people to actively halt the expression of others, therefore, researchers need to include, but ultimately move beyond, subjects as weighty as race and ideology. Censorship is defined herein as any attempt to shield others from content that the censor finds objectionable or that he or she assumes others will, or should, find objectionable. ${ }^{54}$ Using that definition, censorship and tolerance are conjoined in that censorship is simply a mechanism by which intolerance is exhibited. Indeed, censorship in all contexts can be regarded as intolerance. ${ }^{55}$ Censorship has both an attitudinal and a behavioral dimension, both of which are necessary. A mere desire to suppress others' expression is not censorship, nor is it censorship to suppress others' speech for reasons unrelated to content. ${ }^{56}$

Popular discussions and scholarly examinations of censorship are often addressed through the metaphor of the marketplace of ideas $^{57}$ and are focused on the ways in which censorship limits people's

Communication Law and Policy, Vol. 15, No. 4 (September 2010): pg. 365-403. DOI. This article is (C) Taylor \& Francis (Routledge) and permission has been granted for this version to appear in e-Publications@Marquette. Taylor \& Francis (Routledge) does not grant permission for this article to be further copied/distributed or hosted elsewhere without the express permission from Taylor \& Francis (Routledge). 
access to "diverse and antagonistic sources of information." 58 But understanding the full scope of censorship requires that one look not only at the broad subjects of social discourse and at attempts by censors to shield others from "noxious doctrine"59 or "hated ideas,"60 but also at more self-focused attempts by censors to preserve their own interests and reputations. There are several studies that show a connection between people's tolerance levels and the proximity of the issue involved, particularly where an issue relates directly to the subjects' self-interest. ${ }^{61}$ Those studies tend to operationalize selfinterest by singling out issues about which people feel particularly passionate or in which they have some personal stake, but that are still external. There is a finer grade of self-interest, however, that is typically overlooked and that is self-preservation - people's impulse to take or support actions designed to preserve their reputations and public standing. ${ }^{62}$ Censorship studies using surveys and interviews often probe issues of special interest to the interviewer or interviewee, but they rarely present scenarios in which the interviewees themselves are the subjects of the triggering content. ${ }^{63}$

\section{Content Triggers and Demographic Patterns}

Studies on censorship and tolerance have consistently shown a disparity between people's support for the broad principles of pluralism and free expression and their willingness to support restrictions targeting particular groups, ideas or types of expression. ${ }^{64}$ This is intuitive in that rights are usually expressed as "concepts" rather than "conceptions," 65 but this lack of specificity in research queries adds some imprecision to censorship research, and it is compounded by the fact that many of these studies are bound to particular issues whose contours change over time. ${ }^{66}$

Despite these complications, there are some characteristics that researchers have found, in a variety of contexts, to be connected with people's tolerance levels and support for free expression. One is that people who are more educated tend to be more tolerant. ${ }^{67}$ Some studies have shown a related disparity between social elites and nonelites, with the former being more tolerant than the latter, ${ }^{68}$ but others suggest that those disparities can be explained by differences in education alone. ${ }^{69}$ In any case, the link between tolerance and 
education is, as Sullivan, Piereson and Marcus put it, "[T]he most durable generalization in this whole area of inquiry." 70 One might therefore expect less censorship on college campuses than in other social settings, although that is not something that is directly measured in this study because there is no parallel context by which to make useful comparisons.

More relevant to this study is the role of gender. Many studies have found women to be less tolerant than men. In the 1950s, for example, Samuel Stouffer showed substantial differences between men and women in their feelings about Communists, with women being less tolerant. ${ }^{71}$ Clyde Z. Nunn, Harry J. Crockett and J. Allen Williams replicated Stouffer's study in the 1970 s and found that the gap between men and women had widened. ${ }^{72}$ They speculated that the differences were explained by the fact that men focused on the political and economic dimensions of Communism while women focused on its anti-religious characteristics. ${ }^{73}$ Sullivan, Pierson and Marcus suggested in 1982 that there are clear gender differences in terms of what people select as their "least liked group," but that males and females are equally intolerant of the groups they put in their leastliked categories. ${ }^{74}$ However, in a 1995 study, Marcus and Sullivan, together with Elizabeth Theiss-Morse and Sandra L. Wood, found women to be less tolerant than men both in their attitudes about particular groups and in their "standing decisions" - essentially, their tolerance baselines - although the differences were not large. ${ }^{75}$

Several studies have shown women to be more supportive of censorship than men, ${ }^{76}$ although the differences are often linked to specific types of content, particularly pornography ${ }^{77}$ and other sexually explicit or violent popular entertainment. ${ }^{78}$ Other studies contradict those findings, however. ${ }^{79}$ Several studies have found no difference between men and women in their general attitudes about censorship. ${ }^{80}$ Richard Hense and Christian White, for example, found that even though women were more supportive of censoring pornography than men, their general censorship scores were parallel to those of the male respondents. ${ }^{81}$ Collectively, the research does not warrant an expectation of gender disparities in the newspaper theft context; nevertheless, one would expect any observed differences to show more involvement by women than men. 
Research on censorship has addressed antecedent or predictor variables as well. Some studies suggest that conservatives are less tolerant and more likely to support censorship than liberals, ${ }^{82}$ although the results are mixed when the focus is on particular issues. ${ }^{83}$ The research shows a similar relationship between religiosity and censorship, with most studies showing a negative relationship between religiosity and support for free expression. ${ }^{84}$

A key feature of the current research is its focus on acts of censorship rather than attitudes. ${ }^{85}$ This kind of research is uncommon, in part, because it is rare to find contexts in which censorship occurs frequently and conspicuously enough to be measured, but there are some studies on censorship in educational institutions that provide insight. Research on book censorship, for example, shows that librarians and school officials are most concerned with shielding students from content that challenges conventional social mores. Lee Burress found that the top seven reasons (out of twenty-five) for book censorship were obscenity/bad language, sexual references, inappropriate subjects, nudity, violence, moral values, and drug references, ${ }^{86}$ and that only thirty-five of 448 total incidents were triggered by political, religious or racially insensitive content. ${ }^{87}$ L. B. Woods found similar results in a study that included colleges and universities and that looked at a variety of censorship incidents. ${ }^{88}$ Of the 242 incidents identified by Woods at post-secondary institutions, the two most common content triggers were "politics" and "sex and nudity," each accounting for forty-three incidents. The next three most common triggers were "obscenity," "language," and "racism," each accounting for between twenty-five and thirty-seven incidents. ${ }^{89}$ These findings are similar to those of John B. Harer and Steven R. Harris who found that "sexual issues preoccupy the censor,"90 and that of 2,818 censorship complaints at colleges and universities in the 1980s, the three most common content triggers were "sexual," "profane" and "obscene" content. ${ }^{91}$ In addition, 70\% of all censorship attempts were because of concerns about either sexuality or other traditional values issues (content addressing "immoral," "anti-family," or "homosexual" themes, for example). ${ }^{92}$ Censors were also concerned about content that criticized school officials or the government, and about speech that was insensitive to people's race, religion or gender, but these 
were far less common triggers than those relating to sex, morals or inappropriate subjects. ${ }^{93}$

Overall, research suggests that school officials at colleges and universities have four primary sets of concerns: (1) content that is indecent, sexually provocative or that deals with questions of morality; (2) content that challenges the school or the government; (3) content that is insensitive to race, gender or religion; and (4) content that addresses hot-button political subjects, particularly where the censor believes the topic itself (such as abortion or homosexuality) is inappropriate for certain audiences.

\section{Free Speech and Social Learning}

Despite Americans' almost universal public embrace of the general value of free expression, they exhibit a surprising indifference to a variety of specific restraints. In the Freedom Forum's 2007 annual survey, $37 \%$ of respondents said they did not believe "newspapers should be allowed to freely criticize the U.S. military about its strategy and performance," 94 and $61 \%$ said the "government should be allowed to require newspapers to offer an equal allotment of time to conservative and liberal commentators. "95 Perhaps many Americans simply do not accept the largely libertarian interpretation of the First Amendment advanced by the Supreme Court. ${ }^{96}$ But it is just as likely that they are not fully acquainted with the historical roots of the First Amendment and its connection to the values of self-fulfillment, the search for truth and democratic self- governance. ${ }^{97}$ People's acceptance of these rationales, and of the Supreme Court's theoretical and doctrinal framework, requires a certain familiarity with and understanding of the broader constitutional design and mechanisms of government. This might partially explain why those who are more educated tend to be more tolerant and more supportive of free expression. ${ }^{98}$ Indeed, Herbert McClosky and Alida Brill found that those who were "highly informed about civil liberties" were three times as likely to be "highly tolerant" as those who were poorly informed, ${ }^{99}$ and that those with high levels of political sophistication were more likely to demonstrate strong support for free speech and press. ${ }^{100}$ Marcus, Sullivan, Theiss-Morse and Wood also found a strong relationship between people's tolerance levels and their baseline commitments to 
democratic principles, including free speech. ${ }^{101}$ Perhaps those who are more informed are better able to look past the immediate dangers posed by a permissive speech environment and to see the long-term social benefits of free expression, as well as to conceive of it as a core liberty rather than a simple policy preference.

Broad acceptance of free expression requires a certain amount of knowledge, which can be acquired in formal classroom settings and through social learning - the process by which people shape their behavior by observing and taking cues from other role models in society. ${ }^{102}$ Marcus, Sullivan, Theiss-Morse and Wood suggest tolerance is learned just like every other social norm, ${ }^{103}$ and that "social learning is indeed a powerful (perhaps the single most powerful) influence on the adoption of civil libertarian norms." ${ }^{104}$ Indeed, tolerance must be learned because intolerance is the norm to which humans are otherwise predisposed. ${ }^{105}$ According to law professor Vincent Blasi, "The aggressive impulse to be intolerant of others" is a "powerful instinct" that "resides within all of us," and "[o]nly the most sustained socialization - one might even say indoctrination in the value of free speech - keeps the urge to suppress dissent under control."106

In the context of colleges and universities, most students probably exceed the societal norm in their knowledge of democratic and constitutional principles. Nevertheless, many are just beginning to explore those issues and to craft their own conceptions of the appropriate boundary between freedom and restraint. Their opinions are no doubt affected by their coursework but also by their observations of other social actors - faculty, administrators and other students. As a result, this study examines the ways in which newspaper theft incidents were described by all of the parties, with the assumption that those statements not only reflect the sensibilities of those parties but also provide a framework that could be internalized by others.

\section{Research Questions}

One track of this research is focused on law and policy and the other is on censorship and tolerance. The two are overlapping in that law and policy norms help shape people's attitudes and actions,

Communication Law and Policy, Vol. 15, No. 4 (September 2010): pg. 365-403. DOI. This article is (C) Taylor \& Francis (Routledge) and permission has been granted for this version to appear in e-Publications@Marquette. Taylor \& Francis (Routledge) does not grant permission for this article to be further copied/distributed or hosted elsewhere without the express permission from Taylor \& Francis (Routledge). 
including both their propensity to censor and their willingness to speak out against the censorship of others. At the same time, law and policy responses to censorship need to be informed by an understanding of the characteristics of those who are most likely to censor, the content that triggers those responses and a gauge of the real limits of people's tolerances.

The central questions addressed here are:

- How often and in what contexts does newspaper theft occur?

- What types of publications are most likely to be the targets of newspaper theft?

- What types of content, in terms of both form and message, are most likely to trigger newspaper thefts?

- What types of people, in terms of both status (student, faculty, administration) and gender, are most likely to commit newspaper thefts?

- Whose interests do newspaper thieves seek to protect?

- How do law enforcement and university officials respond to newspaper thefts and what punishments do they impose on the thieves?

- How do student journalists, law enforcement and university officials characterize the nature and severity of the harms posed by newspaper theft?

These are the basic questions that shaped the analysis of theft incidents, but the broader aim was to contribute to theories about, and conceptualizations of, censorship and tolerance, while also providing a foundation for policy responses.

\section{Method}

This research was built largely around a content analysis of news stories describing newspaper theft incidents between 1995 and 2008. The start year was chosen because it was the first year for which substantial records exist. Much of the information for this study was gleaned from written accounts produced by the Student Press Law Center (SPLC), a non-profit, public-interest group, which has monitored newspaper theft incidents since 1995. ${ }^{107}$ Additional accounts

Communication Law and Policy, Vol. 15, No. 4 (September 2010): pg. 365-403. DOI. This article is (C) Taylor \& Francis (Routledge) and permission has been granted for this version to appear in e-Publications@Marquette. Taylor \& Francis (Routledge) does not grant permission for this article to be further copied/distributed or hosted elsewhere without the express permission from Taylor \& Francis (Routledge). 
of journalists, theft incidents were accessed using the "Daily Newspapers" database in Lexis-Nexis. ${ }^{108}$ These efforts generated more than 500 stories describing more than 300 theft incidents. ${ }^{109}$ Thefts that did not involve college or university publications were eliminated, as were others for which insufficient information was available, leaving a final list of 295 thefts. ${ }^{110}$

Each of the theft incidents served as a unit of analysis, with information about each incident drawn from at least one, but sometimes several, news accounts. Coders recorded the month and year of each incident to observe any seasonal trends or variations across time. They recorded the state where the incident occurred to identify state/regional patterns. And they noted whether the incidents occurred at public or private universities to see if any there were significant variations by university type. Graduate and undergraduate enrollment figures were also collected for each of the universities involved to help identify size-related disparities and to calculate malefemale student ratios that were specific to the universities in the study as well as to create an aggregate male-female ratio for all of those universities. ${ }^{111}$ Data on the number of papers stolen were drawn from stories about theft incidents, which also often contained circulation figures. ${ }^{112}$ Where circulation numbers were not provided, they were accessed using Bacon's Newspaper Directory. For each incident, the "paper type" was also noted to see whether the targets of the thefts were main campus newspapers or alternative papers and whether they had a declared ideological identity. ${ }^{113}$

A key aim of this study was to understand who engages in newspaper theft. As a result, coders noted (where the information was available) the gender of the thieves and whether they were students, faculty/staff, administrators or members of the public. A distinction was also made between "principal thieves" and other thieves. If a university administrator, for example, enlisted the help of students to confiscate papers, the identity of the students was less important than the identity of the person who ordered the confiscation. In those cases, the characteristics (including gender) of the principal thief (the administrator) were recorded separately. ${ }^{114}$ The total number of thieves was also recorded based on both gender and on whether the thieves were students, faculty, staff or members of the broader public. 
In many cases, the precise number of thieves was unknown, so coders relied on whatever information was available. ${ }^{115}$ If a custodian confiscated papers upon the order of an unknown administrator, coders recorded " 1 " for "administrative thieves" and "unknown" for gender, given the certainty that at least one administrator was involved, and the uncertainty about the involvement of others.

Two of the most important variables were the "reason for the theft" and the broader "concern of the thieves." Both were nominal/categorical variables, the first of which were more than a dozen exhaustive and mutually exclusive categories differentiating between personal attacks, hateful or insensitive speech, false or unflattering portrayals, suggestions of incompetence or wrongdoing, policy disputes, sensitive subjects, vulgar or indecent language, or similar elements. The other key variable was the broader concern of the thieves and whether they were trying to preserve their own interests and reputations or those of others, whether they were trying to shape public dialogue on particular issues, or whether they were acting more as employee-guardians of the interests of the university.

There were twenty-seven coded variables. ${ }^{116}$ After conducting two preliminary tests of the coding scheme with three different coders, a final scheme was adopted and used by two coders who divided the coding load for the whole case list. ${ }^{117}$ They first conducted an intercoder reliability test using sixty randomly selected cases ( $20 \%$ of the total), reaching more than $90 \%$ agreement on every variable, with a range between $90 \%$ and $100 \%$. All discrepancies were resolved by subsequent discussion between the two coders. Given the high levels of agreement, no additional reliability tests were conducted.

Although coding of most variables was straightforward, there were a couple of practical limitations that required the use of some assumptions - one with respect to the identity of the thieves and another with respect to the reason for the theft. In some cases the full identity of the thieves was known because they confessed or were caught. In other cases, aspects of their identity had to be ascertained from either the context or from the statements of the newspaper staff. Because the newspaper staff members were involved so closely with these incidents and were familiar with the full context, the coders

Communication Law and Policy, Vol. 15, No. 4 (September 2010): pg. 365-403. DOI. This article is (C) Taylor \& Francis (Routledge) and permission has been granted for this version to appear in e-Publications@Marquette. Taylor \& Francis (Routledge) does not grant permission for this article to be further copied/distributed or hosted elsewhere without the express permission from Taylor \& Francis (Routledge). 
relied upon their conclusions about the identities of the thieves. If they were uncertain, or if they pointed to two or more equally plausible possibilities, then the items were coded as "unclear." Even in cases where the conclusions of the staff were not provided, the identities of the thieves (at least some of their general characteristics) could sometimes be deduced. The coders therefore worked from the assumption that those who were the targets or subjects of the triggering content were also the thieves, unless the content suggested otherwise or there was another equally likely explanation. ${ }^{118} \mathrm{~A}$ similar approach was used with the reasons for the thefts. In most cases the newspaper staff was certain about the content that triggered the theft. The coders again relied on those conclusions. But if the staff pointed to two or more equally plausible causes, then it was coded as unclear. ${ }^{119}$

Some of the research questions could not be adequately addressed through the quantitative content analysis, so a separate analysis was conducted to learn (1) how the parties characterized the thefts, and (2) how they responded through their formal actions. With respect to the first of these, each story was read to examine how the student body and the administration described the nature of the thefts, including whether they saw it as a genuine threat to free expression and discourse on campus or whether they dismissed or minimized the harms. The thieves' statements about the thefts were also noted to see whether they were contrite or defiant. In addition to looking at the parties' statements, each story was examined to see what steps were taken by the student body, the administration and local law enforcement officials ${ }^{120}$ to investigate the thefts and punish the thieves. The rationales offered for those actions were also noted.

\section{Findings: Quantitative Analysis}

The quantitative analysis was designed to measure how often and in what circumstances newspaper thefts occur, to observe trends over time, and to identify the characteristics of newspaper thieves and the content that triggers their actions. The results of that analysis are presented below. 
NOT THE PUBLISHED VERSION; this is the author's final, peer-reviewed manuscript. The published version may be accessed by following the link in the citation at the bottom of the page.

\section{Frequency and Contexts of Newspaper Theft}

This study identified 295 newspaper theft incidents in the fourteen years studied with an average of 21.2 thefts per year. The Graph shows an inconsistent pattern, although with a spike in 2001 and 2002. In the last two years studied (2007 and 2008), the number of incidents was below the mean for all years. Those are positive signs, although those declines were too small and occurred over too short a period to suggest that newspaper theft is a fading phenomenon. Newspaper thefts are just as common in fall as in spring, with the most activity occurring in November and April. Nearly $80 \%$ of all thefts occur during six months of the year - February, March, April, September, October and November - which follows the rhythm of the school year. There do not appear to be any unusual trends with respect to particular states. The thefts recorded in this study occurred in forty-three of the fifty states and the District of Columbia. Most occurred in California (10.8\%), New York (6.1\%) and Texas (6.1\%), but these numbers track roughly with the state population figures. More striking, at least at first glance, is the disparity in the number of thefts occurring at public universities (72.4\%) versus private $(26.9 \%)$. But these differences are almost exactly in line with national enrollment figures. ${ }^{121}$

Communication Law and Policy, Vol. 15, No. 4 (September 2010): pg. 365-403. DOI. This article is (C) Taylor \& Francis (Routledge) and permission has been granted for this version to appear in e-Publications@Marquette. Taylor \& Francis (Routledge) does not grant permission for this article to be further copied/distributed or hosted elsewhere without the express permission from Taylor \& Francis (Routledge). 
NOT THE PUBLISHED VERSION; this is the author's final, peer-reviewed manuscript. The published version may be accessed by following the link in the citation at the bottom of the page.

\section{Graph:}

Newspaper Theft Incidents by Year

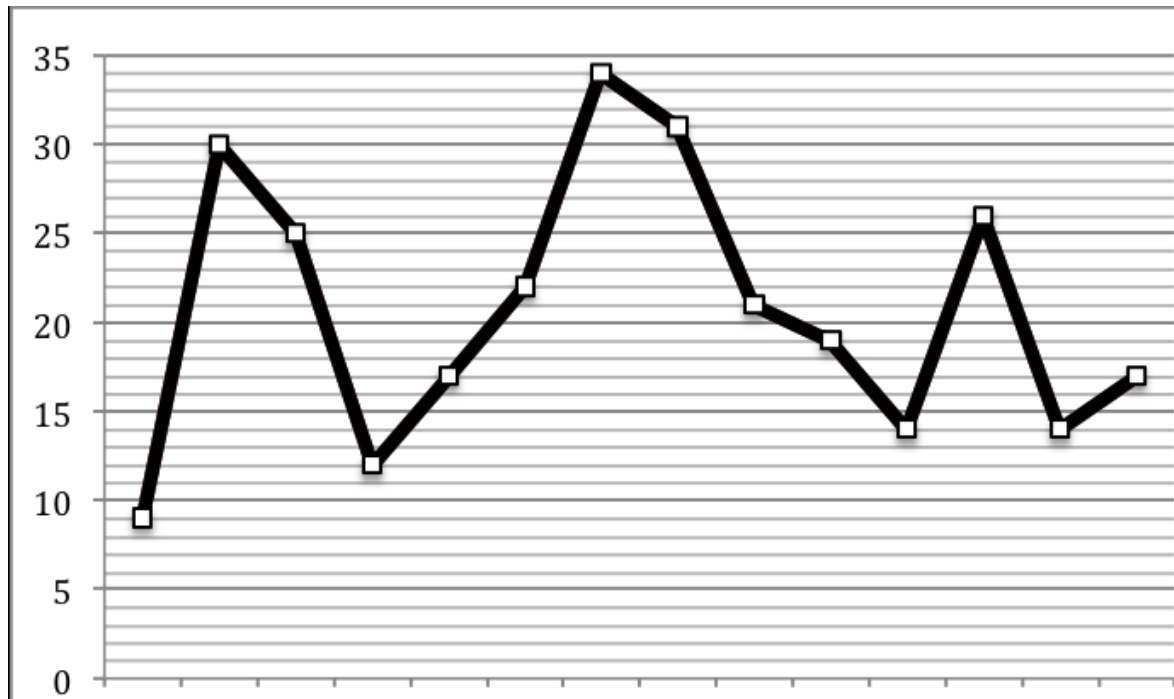

$\begin{array}{llllllllllllll}1995 & 1996 & 1997 & 1998 & 1999 & 2000 & 2001 & 2002 & 2003 & 2004 & 2005 & 2006 & 2007 & 2008\end{array}$

The evidence does not suggest that newspaper thieves disproportionately target alternative papers. Only $8.2 \%$ of thefts were of alternative papers while $89.5 \%$ percent targeted main campus papers. Among the former, there was a clear ideological imbalance in that five times as many thefts were of conservative-alternative papers (twenty) than liberal-alternative papers (four), but the numbers are small and the disparity could simply be a function of there being more conservative-alternative papers on campuses than liberal-alternative papers. ${ }^{122}$ The results certainly do not support the claim by some that "most" newspaper thefts are of conservative publications. ${ }^{123}$

Most newspaper thieves appear to have a clear purpose and employ an aggressive strategy. Thieves stole an average of 2,870 papers per incident, which was just under half $(48.1 \%)$ of the mean circulation for those publications.

\section{Characteristics of Newspaper Thieves}

Students were by far the most common culprits in theft cases. As Table 1 indicates, in $80.2 \%$ of the cases in which the identities of the thieves could be determined, students committed the thefts, and of the 400 thieves whose identities could be determined, $85.5 \%$ were

Communication Law and Policy, Vol. 15, No. 4 (September 2010): pg. 365-403. DOI. This article is (C) Taylor \& Francis (Routledge) and permission has been granted for this version to appear in e-Publications@Marquette. Taylor \& Francis (Routledge) does not grant permission for this article to be further copied/distributed or hosted elsewhere without the express permission from Taylor \& Francis (Routledge). 
students. Members of the campus administration were responsible for $9.9 \%$ of the thefts and represented $6.0 \%$ of the identified thieves, faculty and staff were responsible for $6.9 \%$ of the thefts and represented $5.8 \%$ of the thieves, and members of the public were responsible for $2.6 \%$ of the thefts and represented $2.8 \%$ of the thieves. ${ }^{124}$ Students who were associated with either student government or Greek-letter organizations committed a significant number of thefts. There were thirty-one incidents in which the newspaper thieves were affiliated with student government, and fortyone cases in which the thieves were associated with fraternities or sororities. ${ }^{125}$

\section{Table 1:}

Identity of principal thief/thieves with percentages of total cases and cases where identity known.

\begin{tabular}{lccc}
\hline $\begin{array}{l}\text { Identity of } \\
\text { Principal } \\
\text { Thief/Thieves }\end{array}$ & $\begin{array}{c}\text { Total } \\
\text { Cases }\end{array}$ & $\begin{array}{c}\text { Percent of } \\
\text { All Cases }\end{array}$ & $\begin{array}{c}\text { Percent of Cases } \\
\text { Where Identity } \\
\text { Known }\end{array}$ \\
\hline Student(s) & 186 & $63.1 \%$ & $80.2 \%$ \\
Faculty/Staff & 16 & $5.4 \%$ & $6.9 \%$ \\
Administration & 23 & $7.8 \%$ & $9.9 \%$ \\
Public & 6 & $2.0 \%$ & $2.6 \%$ \\
Mixed & 1 & $.3 \%$ & $.4 \%$ \\
Unclear & 63 & $21.4 \%$ & $n / a$ \\
\hline Total & 295 & $100 \%$ & $100 \%$ \\
\hline
\end{tabular}

There were 135 cases in which the gender of the principal thief or thieves could be ascertained. As Table 2 indicates, males were the principal thieves in $68.1 \%$ of those cases; females were the principal thieves in $27.4 \%$. The gender of the principal thieves was mixed in $4.4 \%$ of cases. The percentages were similar for the total number of thieves: $70.8 \%$ percent of the 209 thieves whose gender could be determined were male and only $29.2 \%$ female. These disparities are even more remarkable in light of the fact that, cumulatively, there

Communication Law and Policy, Vol. 15, No. 4 (September 2010): pg. 365-403. DOI. This article is (C) Taylor \& Francis (Routledge) and permission has been granted for this version to appear in e-Publications@Marquette. Taylor \& Francis (Routledge) does not grant permission for this article to be further copied/distributed or hosted elsewhere without the express permission from Taylor \& Francis (Routledge). 
were more females than males at the universities where these theft incidents occurred. The aggregate male-female ratio of those universities, using a per capita measure to account for the enrollment differences, was $53.8 \%$ female to $46.2 \%$ male. ${ }^{126}$

Table 2:

Gender of principal thief/thieves with percentages of total cases and cases where gender known.

\begin{tabular}{lccc}
\hline $\begin{array}{l}\text { Gender of } \\
\text { Principal } \\
\text { Thief/Thieves }\end{array}$ & $\begin{array}{c}\text { Total } \\
\text { Cases }\end{array}$ & $\begin{array}{c}\text { Percent of } \\
\text { All Cases }\end{array}$ & $\begin{array}{c}\text { Percent of Cases } \\
\text { Where Gender } \\
\text { Known }\end{array}$ \\
\hline Male & 92 & $30.2 \%$ & $68.1 \%$ \\
Female & 37 & $12.5 \%$ & $27.4 \%$ \\
Combination & 6 & $2.0 \%$ & $4.4 \%$ \\
Unclear & 160 & $54.2 \%$ & $n / a$ \\
\hline Total & 295 & $100 \%$ & $100 \%$ \\
\hline
\end{tabular}

\section{Triggering Content and Motivations}

Of the 295 thefts, 94\% represented attempts by the thieves to suppress the speech of others. ${ }^{127}$ News or feature stories and photos triggered the most thefts $(60.7 \%)$, with nearly all of the others $(37.6 \%)$ triggered by opinion content, ${ }^{128}$ which included columns, editorials, cartoons, paid political advertising, and humor or parody pieces. Of the ninety cases in which the triggering content was opinion, seven involved material published in an April Fool's or other parody issue, which is lower than might be expected given how much controversy those publications typically generate.

In $18 \%$ of cases, the reason for the theft was unclear. Excluding those cases, as well as those that did not constitute acts of censorship, by far the most common reason for thefts was a suggestion that someone had acted negligently, incompetently or had engaged in some kind of wrongdoing. As Table 3 shows, those accounted for $42.2 \%$ of the cases. ${ }^{129}$ The second most common reason was a more

Communication Law and Policy, Vol. 15, No. 4 (September 2010): pg. 365-403. DOI. This article is (C) Taylor \& Francis (Routledge) and permission has been granted for this version to appear in e-Publications@Marquette. Taylor \& Francis (Routledge) does not grant permission for this article to be further copied/distributed or hosted elsewhere without the express permission from Taylor \& Francis (Routledge). 
generally false or unflattering portrayal (20.9\%), ${ }^{130}$ the third was hate/insensitive speech $(10 \%)$, which included any content that the thieves regarded as racist, sexist or otherwise insensitive to minority groups, ${ }^{131}$ and the fourth was a concern about a broader social or public policy issue (9.6\%). ${ }^{132}$ The majority of newspaper thefts were triggered by content that related to the interests, reputations, privacy and sensibilities of particular individuals rather than to broader political issues and controversies.

Within those broader contexts, the most common national issues were affirmative action and abortion, and the most common local issues were those relating to student government policies and elections. Overall, however, the underlying controversies were too diffuse and the numbers too small to draw any conclusions about the kinds of issues that trigger the thefts. This also makes it difficult to draw comparisons with other censorship studies, which typically focus on particular issues (pornography, violence) or are tied to particular contexts (book censorship at libraries). Nevertheless, it is worth noting that only five thefts were triggered by "indecent, vulgar or profane content," and five others were driven by content that the thieves regarded as inappropriate (drugs, HIV/AIDS, homosexuality). So, concerns about social mores, which are common subjects of censorship studies, were not a significant factor in this context.

Communication Law and Policy, Vol. 15, No. 4 (September 2010): pg. 365-403. DOI. This article is (C) Taylor \& Francis (Routledge) and permission has been granted for this version to appear in e-Publications@Marquette. Taylor \& Francis (Routledge) does not grant permission for this article to be further copied/distributed or hosted elsewhere without the express permission from Taylor \& Francis (Routledge). 
NOT THE PUBLISHED VERSION; this is the author's final, peer-reviewed manuscript. The published version may be accessed by following the link in the citation at the bottom of the page.

Table 3:

Reason for theft with percentages of total cases and cases where reason known.

\begin{tabular}{lccc}
\hline Reason for Theft & $\begin{array}{c}\text { Total } \\
\text { Cases }\end{array}$ & $\begin{array}{c}\text { Percent of } \\
\text { All Cases }\end{array}$ & $\begin{array}{c}\text { Percent of } \\
\text { Cases Where } \\
\text { Reason Known }\end{array}$ \\
\hline Negligence/Wrongdoing & 97 & $32.9 \%$ & $40.1 \%$ \\
False/Unflattering Portrayal & 48 & $16.3 \%$ & $19.8 \%$ \\
Hate/Insensitive Speech & 23 & $7.8 \%$ & $9.5 \%$ \\
Policy Dispute & 22 & $7.5 \%$ & $9.1 \%$ \\
Unrelated to Content & 12 & $4.1 \%$ & $5.0 \%$ \\
Unspecified Disagreement & 8 & $2.7 \%$ & $3.3 \%$ \\
Privacy Invasion & 6 & $2.0 \%$ & $2.5 \%$ \\
Personal Attack & 5 & $1.7 \%$ & $2.1 \%$ \\
Indecency/Profanity & 5 & $1.7 \%$ & $2.1 \%$ \\
Inappropriate Subject & 5 & $1.7 \%$ & $2.1 \%$ \\
Ideological Disagreement & 2 & $.7 \%$ & $.8 \%$ \\
Unauthorized/Illegal Content & 2 & $.7 \%$ & $.8 \%$ \\
Editing/Grammar & 1 & $.3 \%$ & $.4 \%$ \\
Other & 6 & $2.0 \%$ & $2.5 \%$ \\
Unclear & 53 & $18.0 \%$ & $n / a$ \\
\hline Total & 295 & $100 \%$ & $100 \%$ \\
\hline & & & \\
\hline
\end{tabular}

Table 4 shows that in the 233 censorship cases in which the broader concern of the thieves could be determined, $51.9 \%$ involved attempts by the thieves to protect their own interests. ${ }^{133}$ In $8.2 \%$ of cases, the thieves acted on behalf of friends or colleagues or others with whom they had some relationship. In $5.6 \%$ of cases, the thieves acted more as employee-guardians of the interests of the organization to which they belonged rather than as individuals. This usually involved administrators acting to protect their universities. ${ }^{134}$ In $29.2 \%$ of cases the thieves acted out of some external concern - such as a disagreement with the paper's position on an issue of public policy, or

Communication Law and Policy, Vol. 15, No. 4 (September 2010): pg. 365-403. DOI. This article is (C) Taylor \& Francis (Routledge) and permission has been granted for this version to appear in e-Publications@Marquette. Taylor \& Francis (Routledge) does not grant permission for this article to be further copied/distributed or hosted elsewhere without the express permission from Taylor \& Francis (Routledge) 
because they disagreed with the tone or topics addressed in the paper. Two types of external concern were noted. The first involved a general concern with a public policy or other non-personal issue. The second involved an external concern that was more personal to the thieves because it involved race, ethnicity, sexual orientation or other core aspects of their individual identities. The aim was to separate those cases in which the thieves were acting out of an external concern but where the content was still linked in some way to their identities. So, thefts triggered by content that was allegedly insensitive or biased toward particular minority groups were separated from other external cases. Of the $29.2 \%$ of the cases that involved issues that were external to the thieves, $18.5 \%$ were in the first group (externalgeneral) and $10.7 \%$ were in the latter (external-personal).

Table 4:

Concern of thief/thieves with percentages of total cases and cases where concern known.

\begin{tabular}{lccc}
\hline $\begin{array}{l}\text { Concern of } \\
\text { Thief/Thieves }\end{array}$ & $\begin{array}{c}\text { Total } \\
\text { Cases }\end{array}$ & $\begin{array}{c}\text { Percent of } \\
\text { All Cases }\end{array}$ & $\begin{array}{c}\text { Percent of Cases } \\
\text { Where Concern } \\
\text { Known }\end{array}$ \\
\hline Self Concern & 121 & $41.0 \%$ & $51.9 \%$ \\
Relational Concern & 19 & $6.4 \%$ & $8.2 \%$ \\
Institutional Concern & 13 & $4.4 \%$ & $5.6 \%$ \\
External (General) & 43 & $14.6 \%$ & $18.5 \%$ \\
External (Self) & 25 & $8.5 \%$ & $10.7 \%$ \\
Other & 12 & $4.1 \%$ & $5.2 \%$ \\
Unclear & 62 & $21.0 \%$ & $n / a$ \\
\hline Total & 295 & $100 \%$ & $100 \%$ \\
\hline
\end{tabular}

\section{Analysis}

Overall, the data show that newspaper theft is a persistent and widespread phenomenon that is not isolated to particular states, regions or types of universities. Indeed, it is just as common, on a per

Communication Law and Policy, Vol. 15, No. 4 (September 2010): pg. 365-403. DOI. This article is (C) Taylor \& Francis (Routledge) and permission has been granted for this version to appear in e-Publications@Marquette. Taylor \& Francis (Routledge) does not grant permission for this article to be further copied/distributed or hosted elsewhere without the express permission from Taylor \& Francis (Routledge). 
capita basis, at public universities as it is at private ones, even though there are no constitutional barriers to censorship at private universities. There were more thefts by administrators at private universities (fourteen) than at public universities (eleven), but there were no public-private disparities among students. What is more surprising is that twenty-five university officials believed it was appropriate to censor their own campus newspapers (or perhaps they simply assumed they would not be discovered).

Those who steal newspapers represent a broad cross-section of their campus communities, with two exceptions: (1) they are disproportionately aligned with fraternities, sororities and student government, and (2) they are disproportionately male. The latter exception is the most remarkable because the disparity is so stark and because it seems to contradict so much of the censorship literature. Assuming there is no confounding variable that accounts for the malefemale imbalance, it raises a critical question: are men more likely than women to engage in acts of censorship, even if they are no more likely than women to endorse the censorial acts of others? Because most of the prior research is survey-based, scholars need to explore this belief-act nexus in future research, ideally using controlled experiments. The current study was based on examinations of papers that were already published, so it was not possible to control for many variables. It is possible that the differences in gender are simply a function of newspaper content being more focused on male subjects than female. It seems unlikely that this could account for all of the gender differentiation observed here, but it is something that should be explored in future research.

Another important conclusion one can draw from the data above is that most newspaper thefts are triggered by content that is unrelated to controversial public issues. Many of the content triggers identified in previous research on public school and university censorship were not significant factors in triggering newspaper thefts. Thefts were almost never triggered by content focused on sex or morality, nor did hot-button political issues appear to be a common concern among the thieves. Instead, the thieves appeared to be focused largely on the ways in which they were personally portrayed and, secondarily, with issues that were not merely of self-interest, but

Communication Law and Policy, Vol. 15, No. 4 (September 2010): pg. 365-403. DOI. This article is (C) Taylor \& Francis (Routledge) and permission has been granted for this version to appear in e-Publications@Marquette. Taylor \& Francis (Routledge) does not grant permission for this article to be further copied/distributed or hosted elsewhere without the express permission from Taylor \& Francis (Routledge). 
that were linked to core aspects of their identity (race, gender, ethnicity). This raises another important limitation of prior censorship research, which is that it is focused on what people say they will not tolerate, not what they actually seek to suppress when an opportunity presents itself. Nearly all of the censorship literature addresses the attitude-action connection by measuring disparities between respondents' general feelings about people or issues and their willingness to support the suppression of those people or issues. That research does not bridge the disjunction, even though it moves us closer. The current research does not resolve that difficulty either, but it does suggest that the issues around which scholars tend to orient censorship research are perhaps less salient than they suppose, and it suggests that many of those who engage in censorship probably overestimate the extent to which their suppression of politically or sexually charged content is consistent with the real concerns of the public.

Related to this is the fact that in the vast majority of newspaper theft incidents, the thieves acted out of a desire to preserve their own interests rather than to affect public debate over broader social or political issues. Previous research shows that support for censorship is higher when the underlying content is linked in some way to the respondents' interests. The findings here suggest an extension of that principle: People's censorial impulses are even stronger when the triggering content is tied not merely to their self-interest but to their self-preservation - that is, to their reputations and public standing. This study suggests that future research continue examining not only how people respond to content that is of interest to them but also how they respond to content that is about them.

\section{Findings: Qualitative Analysis}

Because the initial reporting on many theft incidents focused solely on the facts surrounding the thefts rather than any subsequent proceedings, it was unclear in many cases whether university or law enforcement officials investigated the thefts or imposed any punishments. Nevertheless, there were 193 cases in which at least some of this information was provided. Sometimes this was simply an indication that an investigation had begun, but overall there was 
enough information to be able to draw some conclusions about the most common responses of the parties, the kinds of obstacles that typically arise, and the ways in which the parties conceived of the nature and consequences of these acts.

\section{Responses to Newspaper Thefts}

It is clear from the reporting on thefts that in most cases administrators and law enforcement officials did not share the student journalists' concerns. They were often disinclined to take any action, and when they did, their approaches were less aggressive - and their punishments less severe - than what the newspaper staffs expected. To be sure, there were many instances in which campus police did investigate these incidents and in which university officials took action against the thieves. But perhaps more notable were the eighty-three cases (43\%) in which university and law enforcement officials ignored the incidents or impeded the investigations, not to mention the dozens of other cases in which university officials or disciplinary boards imposed nominal punishments.

The biggest hurdle was legal. In thirty-three cases police, prosecutors or university officials explicitly declared that they could not act because they did not believe that taking freely distributed publications constituted theft. There were another ten cases in which the police either expressed doubt about the criminality of the theft or in which the police initially rejected the students' requests but later, after learning more about the legal issues, changed course and agreed to look into the incident.

In some cases, campus police seemed sincere in their concern about these incidents but simply felt stymied by the legal ambiguities. After 4,000 copies of the Vista were stolen at the University of Oklahoma, Public Safety Director Jeff Harp acknowledged that the culprits "stole newspapers," but said "from a theft perspective, it's very difficult to establish the requirements under law of a [violation] of that statute."135 In other cases, officials dismissed theft incidents as simply "not a big issue." ${ }^{136}$ And in a few cases they were openly hostile. After a school administrator confiscated 400 copies of an alternative paper at Clark University, campus police said it was not a

Communication Law and Policy, Vol. 15, No. 4 (September 2010): pg. 365-403. DOI. This article is (C) Taylor \& Francis (Routledge) and permission has been granted for this version to appear in e-Publications@Marquette. Taylor \& Francis (Routledge) does not grant permission for this article to be further copied/distributed or hosted elsewhere without the express permission from Taylor \& Francis (Routledge). 
violation, because it was "simply a matter of newspapers being moved from point $A$ to point $B .{ }^{137}$ As the report points out, however, "point $\mathrm{B}^{\prime \prime}$ was a dumpster.

The most common response from school officials and campus police was that there was simply nothing they could do. ${ }^{138}$ But in many of those cases, police appeared to react dismissively without really understanding the state of the law. In some cases, campus police were not aware, until the newspaper staff members informed them, that newspaper thieves had been prosecuted in the past in their states. ${ }^{139}$ In addition, the justifications used by campus police for their inaction varied substantially from one campus to the next and seemed often to be based on speculation. At some schools, police said they could not act because free newspapers have no value and can be taken with impunity. ${ }^{140}$ At other schools, police said newspaper thefts were only criminal if the papers contained notices indicating that readers must pay if they want more than one copy. ${ }^{141}$ Yet some campus police officers refused to investigate thefts of papers that did contain payment notices. Police at the University of Wisconsin-Stout, for example, refused to investigate multiple thefts of the Stoutonia, even though the paper's staff explained to police that a payment notice appeared on the masthead of every copy, ${ }^{142}$ and police at Western Oregon University refused to act on a theft of the Journal because its payment notice appeared only in the paper and not also on the distribution bins. ${ }^{143} \mathrm{~A}$ payment notice also proved inconsequential at the University of Southern Maine where a local prosecutor refused to charge three fraternity members who stole 1,000 copies of The Free Press, because the prosecutor could not prove that the students would not, at some point in the future, pay for the extra 997 copies. ${ }^{144}$ And in another case, campus police said they would not pursue a thief because it would be impossible to prove that he knew his actions were criminal. ${ }^{145}$

Many administrators also used the legal uncertainties to justify their inaction. This would be easier to defend if they were merely acknowledging the difficulty of securing a criminal conviction, but many administrators treated the legal ambiguity as foreclosing any action against the thieves. After 8,000 copies of the Highlander were stolen at the University of California-Riverside, Vice Chancellor Jim 
Sandoval said that "[b]ecause [the papers] were left at a public distribution bin and there were no limits as to how many copies students could take, we did not investigate." Sandoval added: "I clearly understand the frustration of our student newspaper but there was just a limit as to how much we could do."146

It was clear that in many of these cases, campus police and administrators made no attempt to explore the legal issues and that some were actively seeking a way to justify their inaction. In the fortythree cases referenced above, they did this by citing deficiencies in the law. But there were another forty cases in which campus police or administrators refused to act for reasons unrelated to the law, or for reasons that were simply not specified in the published accounts. ${ }^{147}$ The most extraordinary cases were those in which university officials were actually responsible for the thefts or condoned them. No punishment was imposed on a Clark University dean who dumped 400 copies of an alternative paper in the trash, saying "[T]hey're bad for Clark."148 Drew University refused to take action against admissions personnel after they stole copies of the campus paper during orientation week. ${ }^{149}$ And at LaRoche University, the university president publicly endorsed a dean's removal of the paper after concluding that one of its articles conflicted with the religious mission of the school. ${ }^{150}$ This broader concern for the reputation of the university was also a factor at the University of Southern Indiana where officials reportedly decided, for the "good of public relations," to not file a criminal complaint. ${ }^{151}$ The same was true at many other universities where officials decided to deal with these incidents internally without involving law enforcement.

Aside from concerns about legal entanglements, campus police and university officials often appeared indifferent to theft incidents and in some cases deliberately stonewalled. In two cases police refused to act even though they had surveillance video identifying the culprits, ${ }^{152}$ and in one case the police dropped the investigation after misplacing their initial report. ${ }^{153}$ Prosecutors, too, were reluctant to pursue these cases. In four instances they refused to act after criminal complaints were filed. 
Another problem, at least from the perspective of the newspaper staffs, was that even when the culprits were identified, the punishments imposed were not substantial. There were only fifteen cases in which some criminal action was undertaken. In eight of those cases, the outcome was unclear from the reports, which only noted that a criminal complaint was filed or that someone had been charged or was awaiting trial. There were five cases in which there were reports of an outcome in a criminal case. In one case, two students were convicted of petty larceny but their sentences were not known. In three cases the sentences were light: one student was put on probation, one was required to perform community service, and one was fined $\$ 50$. In the fifth case a judge acquitted a student of a misdemeanor, and in doing so rejected the legal foundation for the charge. "If someone throws fliers in someone's yard," Judge Bonnie Jackson said, "and that person picks them up and burns them, do they belong to the thrower or to that person picking them up?"154 In another case, the university dropped a criminal charge after the suspect hired a lawyer, ${ }^{155}$ and a prosecutor in Berkeley initially filed petty theft charges against two student thieves but rescinded them after concluding that the university would be able to impose a harsher sentence than a judge. ${ }^{156}$

That prosecutor's assumption might have been correct, given all the evidence from the criminal context. That is not to suggest, however, that university officials or disciplinary boards were particularly harsh. In many cases the culprits were given nominal punishments - such as a mandatory apology - and some were given warnings, probation or no punishment at all. There were several notable exceptions. In the most extreme case, officials at San Francisco State University expelled a student after he stole 6,000 copies of the Golden Gater. ${ }^{157}$ And several other universities imposed multi-pronged punishments that included public apologies, community service and financial restitution ranging from $\$ 100^{158}$ to $\$ 4,800 .{ }^{159} \mathrm{~A}$ few universities were more creative in their approaches - in one instance requiring the thieves to write an essay on free speech, ${ }^{160}$ in another making a university official attend lectures on the First Amendment, ${ }^{161}$ and in another requiring the thief to paint the offices of the student newspaper. ${ }^{162}$ 
Nevertheless, when examining the totality of punishments imposed on newspaper thieves over the past fourteen years, it would be impossible to conclude that newspaper thieves - when they are caught - are likely to suffer significant consequences as a result of their actions.

\section{Characterizations of Newspaper Thefts}

The division between student journalists and university and law enforcement officials appears to be largely a consequence of the parties' divergent conceptions of the nature and severity of the violation posed by these acts. The student staff members of the targeted publications nearly always treated the thefts as serious violations of their expressive rights as well as robberies of their time, effort and resources. Campus police, on the other hand, tended to apply a strictly legal-economic calculus. There was only one instance in which a law enforcement official mentioned the expressive or First Amendment implications of newspaper theft. ${ }^{163}$ This is perhaps understandable, given their professional charge. But if more of them conceived of newspaper thefts as acts of censorship, they would presumably be more eager to follow up, if only by forwarding the complaints to university officials or conducting preliminary investigations. What many student journalists discovered, however, was that their complaints died at the door of the police station.

The students, of course, were much more likely to regard the thefts as criminal acts, and much more eager to see the culprits caught and punished, than were the police, prosecutors or administrators. The students often had to prod those officials to take action, and in several cases the students had to educate those officials about the state of the law. ${ }^{164}$ Unlike campus police, who were mostly disinterested in these incidents and tended to characterize them as either not criminal or as merely missing-property cases, ${ }^{165}$ the students emphasized the fact that newspaper theft is a crime but also an "intellectual sin,"166 and that those who take newspapers are "stealing freedom of speech and freedom of the press."167

The divide between student journalists and university officials was narrower than with law enforcement, but university officials' 
responses were much less predictable. In twenty-five cases, university officials were known to be among the thieves, and in dozens of other cases they either disregarded the concerns of the student journalists or minimized the thefts as "pranks,"168 acts of "vandalism,"169 or, in one case, "a learning experience" for the thieves. ${ }^{170}$ Nevertheless, there were twenty-two cases in which the reports describe specific condemnations by university officials of theft incidents on their campuses. In a few of those cases, university officials spent as much time criticizing the triggering content as they did the thefts. ${ }^{171}$ And in some cases, officials based their condemnations on issues other than free expression, ${ }^{172}$ or focused on the loss to readers who, as a result of the thefts, were denied access to the paper. ${ }^{173}$ But in other cases the statements clearly emphasized the expressive consequences of newspaper theft and condemned these acts in strong terms. ${ }^{174}$

The information gleaned from news accounts of newspaper theft incidents provides an insufficient foundation for drawing definitive conclusions about the state of mind of university administrators or how they conceive of the nature and seriousness of these acts. Still, it is difficult to look at the totality of the record - the officials' public statements, the percentage of cases they investigated and the substantiality of the punishments they meted out - and conclude that, as a whole, they regarded newspaper theft as censorial, much less as affronts to the broader intellectual integrity of their universities.

\section{Analysis}

Unlike most traditional forms of censorship, newspaper theft clearly presents a conceptual puzzle for many administrators and law enforcement officials. In addition to routinely exhibiting confusion or ignorance about the legal implications of newspaper theft, university and law enforcement officials seem to have no shared sense of the nature of the violation. Some clearly view these acts as brazen abuses; many others dismiss them as mere discourtesies.

The student journalists, on the other hand, were almost unanimous in their treatment of newspaper theft as an act of censorship/intolerance. They did not always say so explicitly, but their actions clearly suggested a sense of violation that went beyond the 
loss of property. Of course, there may have been some student journalists who chose not to complain about the thefts of their newspapers, and so their perceptions would not have been reflected in the news accounts evaluated in this study. Nevertheless, one cannot ignore the close alignment in the students' responses in nearly all of the hundreds of news stories studied here. The students seem to be working from a common framework in which newspaper theft is understood as censorial. The students' responses are also consistent with the conceptual and operational definitions of censorship and intolerance suggested in this article, in that the students generally do not differentiate between cases in which thieves steal papers as acts of self-preservation, for example, and cases in which the thieves seek to reshape the trajectory of a policy debate. In either case, the thieves' objective is to derail the editorial process by overriding the choices of editors and burying their creative and intellectual work.

Given the disparities between the students' conceptualization of newspaper theft and the one - or ones - embraced by university and law enforcement officials, it is not surprising that their responses to these incidents are so divided. If there is to be any kind of uniformity in the law, and any consistency in university policy on these issues, it has to start with some accord on these basic conceptual questions.

\section{Conclusion}

Newspaper theft is a persistent problem that continues to impair the expressive freedom of student journalists and undermines the discourse on college and university campuses. Law enforcement and university officials have done little to create a deterrent. They are as likely to ignore theft cases entirely as they are to aggressively investigate them and impose substantial punishments. As a result, many student journalists have come to expect that newspaper thefts will continue and that whatever recourse they find will be through their own initiative - negotiating with the thieves, filing civil suits, or lobbying legislatures for statutory protection.

The disconnection between students and university and law enforcement officials is largely the product of conflicting conceptions of censorship. The students tend to regard newspaper thefts as

Communication Law and Policy, Vol. 15, No. 4 (September 2010): pg. 365-403. DOI. This article is (C) Taylor \& Francis (Routledge) and permission has been granted for this version to appear in e-Publications@Marquette. Taylor \& Francis (Routledge) does not grant permission for this article to be further copied/distributed or hosted elsewhere without the express permission from Taylor \& Francis (Routledge). 
inherently censorial and as personal, organizational and intellectual violations. University and law enforcement officials, however, tend to treat these cases as either ill-mannered pranks or as minor property violations. Because the law is ambiguous in many jurisdictions, there is little incentive for these officials to act aggressively when they already lack a more principled motivation. Reorienting university policies and practices regarding newspaper theft will require officials to change their conceptions of what newspaper theft is and how to properly calculate its immediate and long-term consequences.

The staffs of student newspapers need not stand by and wait for school officials to reach these epiphanies. The students - along with other partners, such as advisers, local journalists and faculty members - can seek meetings with officials to reinforce the value of free expression and to explain how it is undermined by newspaper theft. They can work with school officials and student government organizations to craft school policies and honor code provisions that explicitly prohibit this form of censorship and that provide significant and predictable penalties. They can educate school officials, student government leaders, fraternity and sorority members, campus police and others about the state of the law, and they can go one step further by seeking to change the law by lobbying for state statutes and local ordinances to prohibit the theft of freely distributed publications. ${ }^{175}$

Of course, none of this should absolve school officials from their obligation to follow the law, uphold their student conduct codes, and serve as diligent guardians of the free exchange of ideas on their campuses. They can serve these ends through their public pronouncements and informal interactions with various stakeholders. They can also do it in more formal ways by adopting specific school policies, adding language about newspaper theft to faculty and student handbooks, requiring training tutorials or workshops for campus police, and consulting with their lawyers about the school's legal obligations and potential liability. Perhaps most important, however, is that more school officials begin to shift their assumptions about newspaper theft and to conceive of it as an act of censorship and as an affront to the educational aims of their institutions. 
The content-analysis data presented here suggest that scholars, too, need to reevaluate the meaning of some core concepts and to reconsider the validity of some of their research assumptions and the utility of some of their methods. Most of the research on censorship and intolerance has focused on attitudes rather than actions. The attitudinal studies are useful, but as the data here suggest, they are not always reliable predictors of what drives people to censor. Research in this are needs to focus more on the behavioral dimensions of censorship rather than antecedent attitudes. This study suggests that gender differences, for example, might only present themselves in the context of actual censorship, so the attitudinal measures might be misleading, or at least insufficient. Research needs to move beyond the acute studies examining people's feelings and reactions to particular types of controversial content and to focus more on people's basic psychological tendency toward self-preservation as an explanation for censorship across substantive contexts. This study suggests that, at least in the context of newspaper theft, censors are mostly concerned with protecting or burnishing their own image rather than shielding the public from toxic ideas. Those who attempt to halt or punish the spread of those ideas might therefore be misdirecting their efforts, or, at the very least, underestimating the depth of the public's concern. And there may be many others who engage in or endorse speech-suppressive acts and policies by invoking the public interest when their real concern is self-preservation.

\section{References}

1 Healy v. James, 408 U.S. 169, 180 (1972).

2 The phrase "newspaper theft" refers to the theft of all freely distributed student publications, including newspapers, magazines, journals and yearbooks.

3 See, e.g., Mary Jordan, Students Who Set Off Penn Newspaper Censorship Uproar Won't Be Punished, WASH. POST, Sept. 15, 1993, at A12. See also Across the Country, Newspaper Thefts Abound, SPLC REPORT, Spring 1999, at 26 (quoting former Student Press Law Center Executive Director Mark Goodman, who noted that newspaper thieves are rarely caught and when they are they "rarely face significant punishment.").

4 Some scholarly articles address newspaper theft as an educational or public-policy problem but none attempt to quantify the frequency and

Communication Law and Policy, Vol. 15, No. 4 (September 2010): pg. 365-403. DOI. This article is (C) Taylor \& Francis (Routledge) and permission has been granted for this version to appear in e-Publications@Marquette. Taylor \& Francis (Routledge) does not grant permission for this article to be further copied/distributed or hosted elsewhere without the express permission from Taylor \& Francis (Routledge). 
contexts in which it occurs or to identify the content triggers or profiles of the thieves.

5 Newspaper thefts often force the staff to choose between paying for a reprinting or refunding the fees from advertisers.

6 This occurs when speech is suppressed in response to the anticipated - or the demonstrated but irrational - response of audience members. See generally Cheryl A. Leanza, Heckler's Veto Case Law as a Resource for Democratic Discourse, 35 HOFSTRA L. REV. 1305 (2007).

7 See Clay Calvert, All the News That's Fit to Steal: The First Amendment, a 'Free Press,' and a Lagging Legislative Response, 25 LOY. L.A. ENT. L. REV. 117, 118 (2004-05). Officials often overlook the fact that the newspapers have value - not merely in terms of the tangible product and the labor required to produce it, but also in terms of the advertising revenue that is lost when the papers are stolen.

8 See infra notes 138-53 and accompanying text.

9 See, e.g., Thieves Filch Newspapers at 6 Colleges, SPLC REPORT, Spring 2000 , at 8 .

10 See, e.g., John Leo, College Coward of the Year, N.Y. DAILY NEWS, Jan. 1, 2000, at A25 (criticizing administrators at the University of Central Arkansas, Georgetown University and California State UniversitySacramento for their refusal to condemn newspaper thefts that occurred on their campuses).

11 See, e.g., Dale Russakoff, At Penn, the Word Divides as Easily as the Sword, WASH. POST, May 15, 1993, at A1 (describing the backlash against University of Pennsylvania President Sheldon Hackney for his refusal to condemn those who stole 14,000 copies of the Daily Pennsylvanian to protest its allegedly racist content).

12 See infra notes 46-63 and accompanying text.

13 See, e.g., FREEDOM FORUM, STATE OF THE FIRST AMENDMENT 2008 (2008); JOHN B. HARER \& STEVEN R. HARRIS, CENSORSHIP OF EXPRESSION IN THE 1980S: A STATISTICAL SURVEY (1994); GEORGE E. MARCUS, JOHN L. SULLIVAN, ELIZABETH THEISS-MORSE \& SANDRA L. WOOD, WITH MALICE TOWARD SOME (1995); JOHN L. SULLIVAN, JAMES PIERESON \& GEORGE E. MARCUS, POLITICAL TOLERANCE AND AMERICAN DEMOCRACY (1982).

14 Vincent Blasi suggests that people's instinctive urge to censor is moderated by their socially conditioned embrace of First Amendment values. Vincent Blasi, The Pathological Perspective and the First Amendment, 85 COLUM. L. REV. 449, 457 (1985).

15 See Jack M. Mcleod, Mira Sotirovic, Paul S. Voakes, Zhongshi Guo \& Kuang-yu Huang, A Model of Public Support for First Amendment Rights, 3 COMM. L. \& POL'Y 480, 481 (1998).

Communication Law and Policy, Vol. 15, No. 4 (September 2010): pg. 365-403. DOI. This article is (C) Taylor \& Francis (Routledge) and permission has been granted for this version to appear in e-Publications@Marquette. Taylor \& Francis (Routledge) does not grant permission for this article to be further copied/distributed or hosted elsewhere without the express permission from Taylor \& Francis (Routledge). 
16 This study compares existing survey data about tolerance and the willingness to censor with newly gathered data about newspaper thieves and the content that inspired their actions. It does not show attitude-action disparities among the same subjects, which would require interviews with the actual thieves.

17 See, e.g., WORLD ENCYCLOPEDIA (2005), http://www.encyclopedia.com/topic/censorship.aspx

18 Some definitions of censorship encompass things like prior review and self-censorship, but neither is relevant in the newspaper theft context. See, e.g., BLACK'S LAW DICTIONARY, 8th Ed. (2004) (Censor: "To officially inspect ... and delete material considered offensive."); New York Times v. Sullivan, 376 U.S. 254, 300 (1964) (describing the selfcensorship or "chilling effect" that libel suits by public officials can induce if not sufficiently circumscribed).

19 A few of the newspaper theft cases studied here involved thefts committed for purposes unrelated to speech (to help decorate a homecoming float, for example). Those cases were treated as thefts but not as acts of censorship.

20 The Supreme Court has rejected the notion that the First Amendment circumscribes the exercise of private power, and that non-media parties can invoke it in order to limit media content. See, e.g., Miami Herald Pub. Co. v. Tornillo, 418 U.S. 241, 254-58 (1974). Although some state courts have interpreted their state constitutions as prohibiting some actions by private parties, those decisions are uncommon and not easily relatable to this context. See, e.g., Robins v. Pruneyard Shopping Cntr., 592 P.2d 341 (Cal. 1979).

21 See Coming Up, Inc. v. San Francisco County, 857 F. Supp. 711 (N.D. Cal. 1994).

22 Smith v. Daily Mail Pub. Co., 443 U.S. 97, 103 (1979). Furthermore, if the student victims can show that the officials' actions violated the students' "clearly established" constitutional rights, the students can seek damages under federal civil-rights statutes. 42 U.S.C. § 1983 (2000).

23 See, e.g., Stanley v. McGrath, 719 F.2d. 279 (8th Cir. 1983) (striking down university's denial of funding in response to content of student university newspaper); Joyner v. Whiting, 477 F.2d. 456 (4th Cir. 1973) (striking down university's indefinite withdrawal of funding in response to allegedly discriminatory hiring practices by the student newspaper); Antonelli v. Hammond, 308 F. Supp. 1329 (D. Mass. 1970) (striking down university's prior review policy).

24 See Brown v. Li, 308 F.3d. 939 (9th Cir. 2002) (upholding university's rejection of a graduate student thesis containing a "disacknowledgements" section, used to criticize faculty members).

Communication Law and Policy, Vol. 15, No. 4 (September 2010): pg. 365-403. DOI. This article is (C) Taylor \& Francis (Routledge) and permission has been granted for this version to appear in e-Publications@Marquette. Taylor \& Francis (Routledge) does not grant permission for this article to be further copied/distributed or hosted elsewhere without the express permission from Taylor \& Francis (Routledge). 
25 See Cornelius v. NAACP Legal Defense \& Ed. Fund, 473 U.S. 788 (1984).

26 It should be noted that these conditions are quite rare for college publications. In addition, where they are present, it is merely conceivable, but by no means certain, that a court would rely on them as a justification for giving school officials the authority to seize copies of those publications, because the U.S. Supreme Court has only addressed the relevance of these conditions in the high school context. See Hazelwood v. Kuhlmeier, 484 U.S. 260, 268 (1988).

27393 U.S. 503 (1969).

$28 \mathrm{Id}$. at 513. Even where those conditions are met, a prior restraint is probably still an excessive remedy under Tinker. See, e.g., Antonelli v. Hammond, 308 F. Supp. 1329, 1332 (D. Mass 1970) (holding unconstitutional a public university's prior-review policy designed to prevent distribution of content that was either "obscene" or inconsistent with "responsible freedom of the press").

29484 U.S. 260 (1988).

$30 \mathrm{Id}$. at 273.

31412 F.3d 731 (7th Cir. 2005).

32 Id. at 735 ("We hold, therefore, that Hazelwood's framework applies to subsidized student newspapers at colleges as well as elementary and secondary schools.").

33 See, e.g., Mark J. Fiore, Trampling the "Marketplace of Ideas": The Case Against Extending Hazelwood to College Campuses, 150 U. PENN. L. REV. 1915, 1948 (2002) ("[T]he distinction between the Court's recognition of college free expression and primary and secondary school expression could not be more stark."). The Illinois legislature responded to Hosty by passing a law specifically rejecting the application of Hazelwood to public universities in the state. 110 ILL. COMP. STAT. 13 (2007).

34 See infra Table 1.

35 See Calvert, supra note 7, at 118.

36 See Richard Daigle, Analysis: Collegiate Censorship by Theft, ATLANTA CONST., Mar. 6, 1994, at F1.

37 See Controversial Ad Helps Spike Surge in Theft of Newspapers, SPLC REPORT, Spring 2001, at 7.

38 West's Ann. Cal. Penal Code $\S 490.7$ (effective Jan. 1, 2007).

39 COLO. REV. STAT. § 18-4-419 (2004).

40 MD. CODE ANN., CRIM. § 7-106 (2003).

41 Berkeley, Cal., Mun. Code § 13.54 .030 (2003).

42 See, e.g., John Leo, Stealing Campus Papers is Criminal Act, KNOXVILLE NEWS-SENTINEL, Nov. 9, 1993, at A10; Student Press Law Center, Newspaper Theft Forum, http://www.splc.org/newspapertheft.asp.

Communication Law and Policy, Vol. 15, No. 4 (September 2010): pg. 365-403. DOI. This article is (C) Taylor \& Francis (Routledge) and permission has been granted for this version to appear in e-Publications@Marquette. Taylor \& Francis (Routledge) does not grant permission for this article to be further copied/distributed or hosted elsewhere without the express permission from Taylor \& Francis (Routledge). 
43 Dale Russakoff, At Penn, the Word Divides as Easily as the Sword, WASH. POST, May 15, 1993, at A1.

44 See Mary Jordan, Students Who Set Off Penn Newspaper Censorship Uproar Won't Be Punished, WASH. POST, Sept. 15, 1993, at A12.

45 See, e.g., HERBERT MCCLOSKY \& ALIDA BRILL, DIMENSIONS OF TOLERANCE: WHAT AMERICANS BELIEVE ABOUT CIVIL LIBERTIES 86 (1983) ("[T]he more [people] know about the laws and legal practices governing civil liberties issues, the stronger their support for freedom of speech and press.").

46 SULLIVAN ET AL., supra note 13 , at 2.

47 Id.

48 Id. at 4-5 ("[T] depending on what action he or she is prepared to take.").

49 See, e.g., James W. Protho \& Charles W. Grigg, Fundamental Principles of Democracy: Bases of Agreement and Disagreement, $22 \mathrm{~J}$. OF POLITICS 276, 293-94 (1960) (citing examples of people's unwillingness to act against people or ideas that they say they will not tolerate).

50 See, e.g., Richard T. LaPiere, Attitudes vs. Actions, 13 SOC. FORCES 230 (1934). The author traveled throughout the South with an Asian couple and was only denied service at one out of 250 establishments. He later surveyed those establishments and 118 out of 128 who responded said they would not serve an Asian.

51 See Protho \& Grigg, supra note 49, at 293-94 (suggesting that the disparity is partly a function of apathy in that people will tolerate things that they verbally oppose because they lack the motivation to act).

52 See, e.g., SULLIVAN, ET AL., supra note 13, at 49-51.

53 Id. at 7-10.

54 Some scholars examine censorship as an act of paternalism designed to shield people from harms anticipated by the censor. See, e.g., Hernando Rojas, Dhavan V. Shah \& Ronald J. Faber, For the Good of Others: Censorship and the Third-Person Effect, 8 INT'L J. OF PUB. OPINION RES. 163 (1996). But there are other contexts where censorial acts are driven by the self-interest and self-preservation instincts of the censor rather than by his or her desire to protect others. That is frequently the case with newspaper thefts.

55 This does not mean the censor must feel personally affronted by the content; many censors are driven by a desire to protect others. See generally Richard M. Perloff, The Third-Person Effect: A Critical Review and Synthesis, 1 MEDIA PSYCH. 353 (1999) (providing an overview of research on the "third-person effect" - the tendency among people to

Communication Law and Policy, Vol. 15, No. 4 (September 2010): pg. 365-403. DOI. This article is (C) Taylor \& Francis (Routledge) and permission has been granted for this version to appear in e-Publications@Marquette. Taylor \& Francis (Routledge) does not grant permission for this article to be further copied/distributed or hosted elsewhere without the express permission from Taylor \& Francis (Routledge). 
NOT THE PUBLISHED VERSION; this is the author's final, peer-reviewed manuscript. The published version may be accessed by following the link in the citation at the bottom of the page.

believe that media messages have more powerful effects on others than on themselves.).

56 See supra note 19.

57 The marketplace theory suggests that truth is most likely to emerge in an environment in which people are able to express their ideas free of any interference from government arbiters. Its most notable exponent was Justice Oliver Wendell Holmes. See Abrams v. United States, 250 U.S. 616, 624-31 (1919) (Holmes, J., dissenting). But a version of this theory was articulated centuries earlier. See JOHN MILTON, AREOPAGITICA (J.C. Suffolk ed., 1968).

58 Associated Press v. United States, 326 U.S. 1, 20 (1945).

59 Whitney v. California, 274 U.S. 357, 375 (1927) (Brandeis, J., concurring). 60 HAZEL DICKEN GARCIA \& GIOVANNA DELL'ORTO, HATED IDEAS AND THE AMERICAN CIVIL WAR PRESS (2008).

61 See, e.g., SULLIVAN ET AL., supra note 13 at 184 ("Attitudes that involve self-interest are more consistently related to behavior than those that do not, especially if the attitude is important to the person."); John Sivacek \& William D. Crano, Vested Interest as a Moderator of Attitude-Behavior Consistency, 43 J. OF PERSONALITY \& SOC. PSYCH. 210 (1982); Jason Young, Eugene Borgida, John L. Sullivan \& John H. Aldrich, Personal Agendas and the Relationship Between Self-Interest and Voting Behavior, 50 SOC. PSYCH. Q. 64 (1987).

62 Some scholars have shown that as people's ego-involvement in a message increases, the disparity between their beliefs and actions narrows. See, e.g., William D. Crano, Attitude Strength and Vested Interest, in ATTITUDE STRENGTH: ANTECEDENTS AND CONSEQUENCES (Richard E. Petty \& Jon A. Krosnick eds., 1995). This "involvement" research in communication, however, tends to focus on people's receptivity to messages, rather than their ego-driven desire to halt those messages.

63 Herbert McClosky and Alida Brill found that people are generally less tolerant of content that is personally embarrassing to them. MCCLOSKY \& BRILL, supra note 45 , at 58 . But by this they mean impersonal content, such as obscenity or pornography, that embarrasses the interviewee but that is not about the interviewee.

$64 \mathrm{Id}$. at $48-49$ (noting that while $89 \%$ of respondents supported "free speech for all no matter what their views might be," only $41 \%$ of the same respondents would permit "foreigners who criticize our government to visit or study here," and half would require loyalty oaths for government employees.). Other studies have shown the same generalspecific incongruity. See, e.g., Mary R. Jackman, General and Applied Tolerance: Does Education Increase Commitment to Racial Integration? 22 AM. J. OF POL. SCI. 302 (1978); Herbert McClosky,

Communication Law and Policy, Vol. 15, No. 4 (September 2010): pg. 365-403. DOI. This article is (C) Taylor \& Francis (Routledge) and permission has been granted for this version to appear in e-Publications@Marquette. Taylor \& Francis (Routledge) does not grant permission for this article to be further copied/distributed or hosted elsewhere without the express permission from Taylor \& Francis (Routledge). 
NOT THE PUBLISHED VERSION; this is the author's final, peer-reviewed manuscript. The published version may be accessed by following the link in the citation at the bottom of the page.

Consensus and Ideology in American Politics, 58 AM. POL. SCI. REV. 361 (1964); Protho \& Grigg, supra note 49.

65 See RONALD DWORKIN, TAKING RIGHTS SERIOUSLY 134 (1988).

66 This is true in the short term in that particular events, such as the Sept.

11, 2001, attacks, can temporarily alter people's attitudes. See, e.g., Chris L. Coryn, James M. Beale \& Krista M. Myers, Response to September 11: Anxiety, Patriotism, and Prejudice in the Aftermath of Terror, 9 CURRENT RES. IN SOC. PSYCH. 165 (2004). It is also true in the long term in that the meaning and resonance of certain terms, such as "communist," can change over time. See, e.g., James A. Davis, Communism, Conformity, Cohorts, and Categories: American Tolerance in 1954 and 1972-73, 81 AM. J. OF SOC. 491 (1975).

67 SULLIVAN ET AL., supra note 13, at 29 (summarizing previous research on this linkage).

68 See, e.g., MCCLOSKY \& BRILL, supra note 47, at 77.

69 See, e.g., Robert Jackman, Political Elites, Mass Publics, and Support for Democratic Principles, 34 J. OF POLITICS 753 (1972).

70 SULLIVAN ET AL., supra note 13, at 29.

71 SAMUEL STOUFFER, COMMUNISM, CONFORMITY, AND CIVIL LIBERTIES (1955).

72 CLYDE Z. NUNN, HARRY J. CROCKETT \& J. ALLEN WILLIAMS, TOLERANCE FOR NONCONFORMITY 119 (1978) (finding a difference of $16 \%$ in 1973 compared to $8 \%$ in 1954).

73 Id

74 SULLIVAN, ET AL., supra note 13, at 100-01.

75 MARCUS ET AL., supra note 13, at 77.

76 See, e.g., T.R. ANDERSON \& H. REINHARDT, THE CURRENT STATUS OF FREEDOM OF EXPRESSION IN MINNESOTA (1987); John Immerwahr \& John Doble, Public Attitudes Toward Freedom of the Press, 46 PUB. OPINION Q. 177 (1982); W. Cody Wilson, Belief in Freedom of Speech and Press, 31 J. OF SOC. ISSUES 69 (1975).

77 See Gloria Cowan, Feminist Attitudes Toward Pornography Control, 16 PSYCH. OF WOMEN Q. 165 (1992); Albert C. Gunther, Overrating the $X$-Rating: The Third-Person Perception and Support for the Censorship of Pornography, 45 J. OF COMM. 27 (1995); Richard Hense \& Christian Wright, The Development of the Attitudes Toward Censorship Questionnaire, 22 J. OF APPLIED SOCIAL PSYCH. 1666 (1992); Jennifer L. Lambe, Who Wants to Censor Pornography and Hate Speech?, 7 MASS COMM. \& SOC'Y 279 (2004) (finding women more likely to support censorship of both pornography and hate speech); Rojas et al., supra note 54; Peter Suedfeld, G. Daniel Steel \& Paul W. Schmidt, Political Ideology and Attitudes Toward Censorship, 24 J. OF APPLIED SOC. PSCYH. 765 (1994) (finding women to be more

Communication Law and Policy, Vol. 15, No. 4 (September 2010): pg. 365-403. DOI. This article is (C) Taylor \& Francis (Routledge) and permission has been granted for this version to appear in e-Publications@Marquette. Taylor \& Francis (Routledge) does not grant permission for this article to be further copied/distributed or hosted elsewhere without the express permission from Taylor \& Francis (Routledge). 
NOT THE PUBLISHED VERSION; this is the author's final, peer-reviewed manuscript. The published version may be accessed by following the link in the citation at the bottom of the page.

supportive of censorship of racist, sexist and violent content than men).

78 See Randy D. Fisher, Ida J. Cook \& Edwin C. Shirkey, Correlates of Support for Censorship of Sexual, Sexually Violent, and Violent Media, 31 J. OF SEX RES. 229 (1994).

79 See, e.g., Douglas M. McLeod, William P. Eveland Jr. \& Amy I. Nathanson, Support for Censorship of Violent and Misogynic Rap Lyrics, 24 COMM. RESEARCH 153, 164 (1997) (finding no significant differences between men and women in their support for censorship of violent and sexist rap music).

80 See, e.g., Julie L. Andsanger \& Mark L. Miller, Willingness of Journalists and Public to Support Freedom of Expression, 15 NEWSPAPER RES. J. 102 (1994); McLeod et al., supra note 15, at 498.

81 Hense \& Wright, supra note 77, at 1672.

82 See, e.g., Andsanger \& Miller, supra note 80; McLeod, et al., supra note 15; Rojas et al., supra note 54.

83 For example, McLeod et al., supra note 79, at 164, and Rojas, et al., supra note 54 , at 180 , found conservatives to be more supportive of censorship of sexist and sexually explicit entertainment media, while another study found no significant relationship between political ideology and support for censorship of pornography. See Margaret E. Thompson, Steven H. Chaffee \& Hayg H. Oshagan, Regulating Pornography: A Public Dilemma, 40 J. OF COMM. 73, 81 (1990). Suedfeld, et al., supra note 77 , at 773 , found that Canadian students on the far-left scored high in their willingness to censor, and that while social conservatives scored high on willingness to censor, economic conservatives did not.

84 In terms of people's general attitudes, see, e.g, Rojas et al., supra note 54, at 180; Margaret E. Thompson, The Impact of Need for Cognition on Thinking About Free Speech Issues, 72 JOURNALISM \& MASS COMM. Q. 934, 940 (1995). With respect to particular issues, the results are more mixed. Rojas et al., supra note 54, at 180; Thompson et al., supra note 83, at 81, and Margaret S. Herrman and Diane C. Bordner all found a positive relationship between religiosity and willingness to censor sexually explicit entertainment content. Margaret S. Herrman \& Diane C. Bordner, Attitudes Toward Pornography in a Southern Community, 21 CRIMINOLOGY 349, 360-61 (1983). Lambe, supra note 77, at 294 found a positive relationship between religiosity and the willingness to censor both pornography and hate speech.

85 Most of the studies on tolerance and censorship are based on respondents' projections about what they would tolerate or suppress in hypothetical situations. See, e.g., STOUFFER, supra note 71, at 13-25; SULLIVAN ET AL., supra note 13 , at $1-2$. But those attitudinal measures do not

Communication Law and Policy, Vol. 15, No. 4 (September 2010): pg. 365-403. DOI. This article is (C) Taylor \& Francis (Routledge) and permission has been granted for this version to appear in e-Publications@Marquette. Taylor \& Francis (Routledge) does not grant permission for this article to be further copied/distributed or hosted elsewhere without the express permission from Taylor \& Francis (Routledge). 
necessarily align with what people actually do when presented with the opportunity to suppress others' speech. Such studies are not really measuring tolerance per se; they are, at best, measuring dislikes, or a kind of pre-intolerance. They identify some attitudinal conditions that might be necessary precursors of intolerant acts, but they are not manifestations of intolerance themselves.

86 LEE BURRESS, BATTLE OF THE BOOKS: LITERARY CENSORSHIP IN THE PUBLIC SCHOOLS, 1950-1985 42-43 (1989).

$87 \mathrm{Id}$. Burress tracked censorship in public schools over a span of four decades, ending in the 1980s, so those data are not current, although more recent research suggests a similar concern among censors. See HERBERT N. FOERSTEL, BANNED IN THE U.S.A.: A REFERENCE GUIDE TO BOOK CENSORSHIP IN SCHOOLS AND PUBLIC LIBRARIES (2002).

88 L.B. WOODS, A DECADE OF CENSORSHIP IN AMERICA: THE THREAT TO CLASSROOMS AND LIBRARIES, 1966-1975 124-25 (1979).

89 Id.

90 HARER ET AL., supra note 13 , at 77.

$91 \mathrm{Id}$.

92 Id.

93 Id.

94 FREEDOM FORUM, STATE OF THE FIRST AMENDMENT 20074 (2007) (emphasis added).

$95 \mathrm{Id}$. at 10 (emphasis added).

96 See generally, FRED S. SIEBERT, THEODORE PETERSON \& WILBUR

SCHRAMM, FOUR THEORIES OF THE PRESS 7 (1963) (describing the libertarian model of the press - associated with the United States and Great Britain since the seventeenth century - in which the press is presumptively free from government interference, where the role of the press is to foster informed democratic decision-making and the search for truth, and where the freedom to communicate is preserved for all those with the means to do so).

97 These are the three principal rationales typically offered for the protection of free expression. See ERIC BARENDT, FREEDOM OF SPEECH 20-23 (1985).

98 See supra notes 70-72 and accompanying text. 99 MCCLOSKY \& BRILL, supra note 45, at 372-73.

100 Id. at 86.

101 MARCUS ET AL., supra note 13 , at 77.

102 See ALBERT BANDURA, SOCIAL LEARNING THEORY (1977).

103 MARCUS ET AL., supra note 13, at 416.

104 Id.

105 Id. at 3-4. See also, id. at 415 ("Whereas the impulse to strike down a threatening enemy or an abhorrent idea seems to be a visceral

Communication Law and Policy, Vol. 15, No. 4 (September 2010): pg. 365-403. DOI. This article is (C) Taylor \& Francis (Routledge) and permission has been granted for this version to appear in e-Publications@Marquette. Taylor \& Francis (Routledge) does not grant permission for this article to be further copied/distributed or hosted elsewhere without the express permission from Taylor \& Francis (Routledge). 
NOT THE PUBLISHED VERSION; this is the author's final, peer-reviewed manuscript. The published version may be accessed by following the link in the citation at the bottom of the page.

response that depends only minimally on social learning, the willingness to suffer people or ideas that one finds objectionable depends heavily on the learning of appropriate social norms.").

106 Blasi, supra note 14 , at 457.

107 Even though other mainstream news stories were among those studied here, the majority of the news accounts came from the Student Press Law Center. Because the SPLC champions the rights of student journalists, there was a risk that its stories would be contaminated by the biases of the organization. This was less significant than it might seem. The SPLC stories were straightforward news accounts, often containing quotes from multiple parties, including administrators, campus police and occasionally the thieves themselves. They were not written in a way that highlighted the students' interests to the exclusion of other relevant comments and perspectives. The SPLC does engage in advocacy on these issues, but its leaders' comments on these subjects were usually issued as separate statements or in press releases. To the extent that those comments were included in these stories at all, which was uncommon, they were offset with quote marks and plain attribution. In other words, the director of the organization was treated like any other source. It is no doubt the case that the SPLC staff members were more sympathetic to the concerns of the students, but that is unremarkable in the sense that the students were clearly victims in each of these incidents, and it is unavoidable in the sense that any news organization reporting on these issues could be accused of siding with the newspaper staff members. In any case, those general biases are of little consequence because the questions we asked were not about the good/bad, pro/con dimensions of these incidents but about the factual circumstances (how many papers were stolen, when, by whom, for what reason).

$108 \mathrm{~A}$ few cases were only described in stories found on Lexis-Nexis, but in most cases the Lexis-Nexis stories merely supplemented the more detailed accounts provided by the SPLC.

109 The units of analysis were the theft incidents, not the stories about the thefts. No attention was paid to the attributes of those stories; they just served as an empirical source for information about the incidents.

110 Cases in which papers were stolen for reasons unrelated to content were distinguished from those that were triggered by the content of the publication.

111 Enrollment figures and male-female ratio figures were gathered using the College View Web site. See http://www.collegeview.com.

112 Any conflicting circulation figures were averaged unless it was clear that one was more accurate.

Communication Law and Policy, Vol. 15, No. 4 (September 2010): pg. 365-403. DOI. This article is (C) Taylor \& Francis (Routledge) and permission has been granted for this version to appear in e-Publications@Marquette. Taylor \& Francis (Routledge) does not grant permission for this article to be further copied/distributed or hosted elsewhere without the express permission from Taylor \& Francis (Routledge). 
NOT THE PUBLISHED VERSION; this is the author's final, peer-reviewed manuscript. The published version may be accessed by following the link in the citation at the bottom of the page.

113 Coders relied on the characterizations of the papers (as "liberal" or "conservative") made by the subjects of the news stories. No independent assessment was made of the publications' ideological bent.

114 The same was true if, for example, a male student was upset about a story in which he was criticized, but later three thieves were caught who were men and women. In that case, the gender of the principal thief would be male.

115 This issue arose most often in the case of organized groups, such as teams or fraternities. If a fraternity took responsibility for a theft, but the identities of the specific thieves were unknown, the coders recorded " 1 " for "male thieves" and " 1 " for "student thieves," based on the assumption that at least one male student was involved. No other assumptions would have been reasonable, however, even though multiple thieves might have been involved, and even though one or more females or non-students were involved.

116 The coding instrument and instructions are available from the authors by request.

117 The two authors conducted the first test and the first author and a research assistant conducted the second test and the coding of the full sample.

118 So, for a story about a student getting caught cheating, the context might support the assumption that the student was involved with the theft. But for a story about a student being accused of sexual assault, the thief could just as easily have been the accused or the accuser. Similarly, for a more general story about cheating on campus, it is just as likely that a university administrator stole the papers to save the school from embarrassment as it is that one of the accused students stole the papers. In the latter two cases, the item would be recorded as "unclear."

119 Of course, even with this information available, there is still some unavoidable imprecision. The staff of the paper could simply be wrong, so there is some inherent error in relying on their beliefs. Nevertheless, it is unlikely that there would be any pattern to that error. In addition, the coders had to speculate to some extent about the true motivations of the thieves.

120 This included campus police, city police and local prosecutors or district attorneys.

121 U.S. Dep't of Educ. Inst. of Educ. Sciences, Digest of Education Statistics, Table 2, at http://nces.ed.gov/programs/digest/d08/tables/dt08_002.asp (showing that in 2006 , for example, $74.9 \%$ of all university graduate

Communication Law and Policy, Vol. 15, No. 4 (September 2010): pg. 365-403. DOI. This article is (C) Taylor \& Francis (Routledge) and permission has been granted for this version to appear in e-Publications@Marquette. Taylor \& Francis (Routledge) does not grant permission for this article to be further copied/distributed or hosted elsewhere without the express permission from Taylor \& Francis (Routledge). 
and undergraduate students were enrolled in public universities and $25.1 \%$ were enrolled in private universities).

122 It is likely that more alternative papers are conservative than liberal, because many are founded in order to serve as counterpoise to the main campus papers, which often have reputations for leaning left.

123 See Abby Ellin, Steal This Page, N.Y. TIMES, Jan. 3, 1999, at 4A-7 (citing a study of newspaper thefts by the American Council of Trustees and Alumni).

124 It should be noted that these figures do not permit precise comparisons across sub-groups, because students clearly outnumber administrators and faculty members on college campuses. In addition, these numbers say nothing about what other forms of censorship members of these groups might practice. Certainly there are some school officials, for example, who seek to inhibit or punish school publications by using methods other than theft/confiscation.

125 This does not mean that those organizations orchestrated or endorsed the thefts; only that individual members participated.

126 This was calculated by multiplying the total undergraduate population for each university by the decimal equivalent of its male-female student ratio. The same was done with the male-female ratios of the graduate student populations. The male and female totals from each university were then added together to get an aggregate figure for all universities in the study.

127 In the other cases, the papers were stolen for reasons unrelated to content (to decorate a homecoming float or as a fraternity hazing stunt, for example).

128 This is based on the cases for which data was available. In $19 \%$ of cases the triggering content was unclear.

129 The remaining figures in this section are also based on the exclusion of those cases.

130 This category included cases where, for example, the paper contained a story about low graduation rates among student athletes. This would not be precise enough to regard as a suggestion of wrongdoing or negligence but would nevertheless be embarrassing to some people. The category focused on wrongdoing or incompetence was reserved for cases where the accusation was more targeted to particular individuals.

131 This was distinguished from the category "personal attack" (2.2\% of cases), which was used for instances where the content represented an ad hominem attack on specific individuals that amounted to insults or name calling, as opposed to specific allegations of wrongdoing. The latter would fall into the first category noted above.

Communication Law and Policy, Vol. 15, No. 4 (September 2010): pg. 365-403. DOI. This article is (C) Taylor \& Francis (Routledge) and permission has been granted for this version to appear in e-Publications@Marquette. Taylor \& Francis (Routledge) does not grant permission for this article to be further copied/distributed or hosted elsewhere without the express permission from Taylor \& Francis (Routledge). 
132 This was distinguished from the category "controversial/sensitive issue" ( $2.2 \%$ of cases), which was used for instances where the subject matter itself was considered by the thieves to be an inappropriate topic for coverage in the publication.

133 This included attempts by the thieves to protect the interests of the groups with which they were associated, provided the groups were relatively small and the content could reasonably be expected to reflect upon the reputations of the individual members. So, if members of a fraternity stole papers because of a story about the organization being placed on academic probation, this would be considered a "selfconcern." But a story criticizing Greeks would not.

134 However, if the content reflected on the interests or reputation of the individual administrator or one of his or her colleagues, then it was coded as either a matter of "self concern" or "relational concern," respectively.

135 Student Press Law Center, Newsflash, Newspaper at Okla. University Stolen for Story on Ex-Football Players Facing Trial, Apr. 9, 2002, http://www.splc.org/newsflash.asp?id=402\&year=2002.

136 Student Press Law Center, Newsflash, Sorority Member Admits to Stealing Stetson Newspapers, Oct. 31, 2006, http://www.splc.org/newsflash.asp?id=1361.

137 Newspaper Thefts Spark New Solutions, SPLC REPORT, Spring 1997, at 28.

138 Student Press Law Center, Newsflash, Ore. University Fines Subject of Political Cartoon $\$ 100$ for Newspaper Theft, July 6, 2004, http://www.splc.org/newsflash.asp?id=843.

139 See, e.g., Newspaper Thieves Run Rampant, SPLC REPORT, Winter 199798 , at 10 (noting that campus police at Texas A\&M initially refuse to investigate the theft of 15,000 copies of the Battalion, but relented after student staffers provided information about previous newspaper theft prosecutions in the state).

140 See Prosecutors Ponder the Value of Free Papers After Thefts, SPLC REPORT, Fall 1996, at 17. Some of the thieves had a similar view of the law. See, e.g., Student Press Law Center, "Flying Squirrels" Land in Trouble for Newspaper Theft at Wis. College, May 7, 2003, http://www.splc.org/newsflash.asp?id=609 (describing a note left by a newspaper thief, which said, "Remember: once you put that paper on the stands it is free property, hence we cannot be punished or reprimanded for what we have done.").

141 See Student Press Law Center, Newsflash, Police Investigating Theft of 2,300 Newspapers at Calif. University, July 26, 2004, http://www.splc.org/newsflash.asp?id=730 (quoting campus police officer Mark Signa for the proposition that adding a payment notice is

Communication Law and Policy, Vol. 15, No. 4 (September 2010): pg. 365-403. DOI. This article is (C) Taylor \& Francis (Routledge) and permission has been granted for this version to appear in e-Publications@Marquette. Taylor \& Francis (Routledge) does not grant permission for this article to be further copied/distributed or hosted elsewhere without the express permission from Taylor \& Francis (Routledge). 
critical and that without it "the papers would be considered free and taking more than one would not constitute theft.").

142 See Student Press Law Center, Newsflash, University of Wisconsin Police Refuse to Investigate Theft of 2,000 Student Papers, Feb. 28, 2001, http://www.splc.org/newsflash.asp?id=231.

143 See Ore. University, supra note 138.

144 See Student Press Law Center, Newsflash, Students Escape Criminal Charges in Maine Theft Case, Nov. 9, 2001, http://www.splc.org/newsflash.asp?id=332.

145 See Ore. Univeristy, supra note 138.

146 Criminalizing Theft in Question, SPLC REPORT, Fall 2003, at 30.

147 This is not a reference to instances in which no information was provided; it is a reference to instances in which the only information provided was that the officials refused to investigate.

148 Student Press Law Center, College Newspaper Thefts Reported to the SPLC, 1996-97 School Year, at 2 (1997) (unpublished records on file with the Student Press Law Center).

149 See Students Seeking to Silence Criticism Swipe Papers at 3 College Campuses, SPLC REPORT, Fall 2000, at 26.

150 See College Officials Trash Student Publications, SPLC REPORT, Fall 2004, at 10.

151 Student Press Law Center, Newsflash, Committee, Editor Clash Over Police Report for Stolen Papers, Oct. 20, 2006, http://www.splc.org/newsflash.asp?id=1355.

152 See Student Press Law Center, Newsflash, Man Caught on Tape Stealing Student Newspapers, Mar. 2, 2001, http://www.splc.org/newsflash_archives.asp?id=239\&year=2001.

153 See Papers Stolen After Reporting on Fired Coach, Drug Bust, SPLC REPORT, Fall 2003, at 31.

154 Student Press Law Center, Newsflash, Former LSU Student Acquitted of Damaging Newspapers, June 12, 1998, http://www.splc.org/printpage.asp?id=71\&tb=newsflash.

155 See Morehead State Editor, Adviser Drop Case Against Alleged Newspaper Thieves, SPLC REPORT, Winter 2006-07, at 26.

156 See Criminalizing Theft, supra note 146.

157 See San Francisco School Punishes Newspaper Thief, SPLC REPORT, Spring 1998, at 11.

158 See Ore. University, supra note 138 (describing punishment of students at the Western Oregon University).

159 See Thieves Swipe Thousands of Papers, 23 SPLC REPORT 30 (describing punishment of students at the University of Miami).

160 See City Outlaws Theft of Free Newspapers, SPLC REPORT, Winter 200304 , at 28.

Communication Law and Policy, Vol. 15, No. 4 (September 2010): pg. 365-403. DOI. This article is (C) Taylor \& Francis (Routledge) and permission has been granted for this version to appear in e-Publications@Marquette. Taylor \& Francis (Routledge) does not grant permission for this article to be further copied/distributed or hosted elsewhere without the express permission from Taylor \& Francis (Routledge). 
NOT THE PUBLISHED VERSION; this is the author's final, peer-reviewed manuscript. The published version may be accessed by following the link in the citation at the bottom of the page.

161 See Newspaper Thefts Multiply on Campus, SPLC REPORT, Winter 19992000, at 14 (describing punishment of a dean at Skidmore College).

162 See Controversial Ad, supra note 37 (describing punishment of thieves at Ohio State University).

163 See Student Press Law Center, Newsflash, California Universities Face Rash of Newspaper Thefts, Feb. 28, 2002, http://www.splc.org/newsflash.asp?id=377 (quoting University of Southern California Deputy Chief Bob Taylor who called newspaper theft "a fundamental violation of what we are about as a people and certainly as a university.").

164 See supra note 139.

165 See Student Press Law Center, Newsflash, Pranksters Suspected in Theft of Student Papers at Pa. University, Mar. 5, 2004, http://www.splc.org/newsflash.asp?id=765.

166 Gwendolyn Thompkins, LSU Editor Defends Stories on Klan, TIMESPICAYUNE, May 7, 1996, at A1.

167 Newspaper Thefts Spark New Solutions, SPLC REPORT, Spring 1997, at 28.

168 Student Press Law Center, Newsflash, Newspaper Estimates Loss of $\$ 2,750$ After 3,500 Copies of Paper Stolen, Oct. 14, 2008, http://www.splc.org/newsflash.asp?id=1823.

169 Student Press Law Center, Newsflash, Anonymous Caller Forewarns Student Editor of Newspaper Theft, Apr. 14, 2006, http://www.splc.org/newsflash.asp?id=1244.

170 Sorority Member, supra note 136.

171 Cornell University President Hunter Rawlings issued an equivocal statement after a theft of the Cornell Review, which published an Ebonics parody. See Students Not Laughing at 'Ebonics,' 18 SPLC REPORT, Fall 1997, at 25. At Drew University, vice president for university relations Tom Harris said the university could not condone newspaper theft but that the offending April Fool's edition was "juvenile, it was thoughtless and it was embarrassing, and it was hurtful to just about everyone, especially minority students on campus." Student Press Law Center, Newsflash, April Fool's Day Edition of N.J. College Newspaper Stolen, May 18, 2005, http://www.splc.org/newsflash.asp?id=1008. And at Georgetown University, President Leo O'Donovan did not take action or issue any statement in response to a theft of a conservative-alternative paper, but issued a general condemnation of newspaper theft after copies of the main campus newspaper were stolen. See Leo, supra note 10, at A25.

172 See, e.g., Student Press Law Center, Newsflash, Students Steal Newspapers for Homecoming Floats, Nov. 19, 2004,

Communication Law and Policy, Vol. 15, No. 4 (September 2010): pg. 365-403. DOI. This article is (C) Taylor \& Francis (Routledge) and permission has been granted for this version to appear in e-Publications@Marquette. Taylor \& Francis (Routledge) does not grant permission for this article to be further copied/distributed or hosted elsewhere without the express permission from Taylor \& Francis (Routledge). 
NOT THE PUBLISHED VERSION; this is the author's final, peer-reviewed manuscript. The published version may be accessed by following the link in the citation at the bottom of the page.

http://www.splc.org/newsflash_archives.asp?id=914\&year=2004 (quoting Northeastern State University official Neil Weaver: "The papers are free, the napkins are free. The question is from an ethical standpoint, how should you use stuff that's free?").

173 See, e.g., Student Press Law Center, Newsflash, Four College Papers are Stolen in a Week, Mar. 5, 2003, http://www.splc.org/newsflash.asp?id=566\&year=2003 (quoting Framingham College spokesperson: "We certainly don't tolerate it. By taking newspapers you are interfering with the ability of other students to read it."); Student Press Law Center, Newsflash, IIl. College Football Coach Caught on Tape Trashing Newspaper, Jan. 28, 2003, http://www.splc.org/newsflash.asp?id=542 (quoting Elmhurst College President Bryant Cureton: "The issue of maintaining access to the student newspaper, maintaining the ability of the student newspaper to be published and read, there's no question of where the institution is on that issue.").

174 See, e.g., San Francisco School Punished Newspaper Thief, SPLC REPORT, Spring 1998, at 11 (quoting San Francisco State University President Robert Corrigan: "Teaching and learning can only proper in an environment where free speech flourishes."); Controversial Ad, supra note 37 (quoting University of Wisconsin-Oshkosh Chancellor Richard Wells, saying newspaper theft is "an assault on our most cherished freedom.").

175 It is also wise practice for student publications to attach a price to their publications if readers take more than one copy, and to conspicuously display this policy in the paper an on the distribution bins. This is useful as a practical deterrent but also as a way of concretely demonstrating the value of the publications for purposes of enforcing laws and school policies dealing with the theft of property.

Communication Law and Policy, Vol. 15, No. 4 (September 2010): pg. 365-403. DOI. This article is (C) Taylor \& Francis (Routledge) and permission has been granted for this version to appear in e-Publications@Marquette. Taylor \& Francis (Routledge) does not grant permission for this article to be further copied/distributed or hosted elsewhere without the express permission from Taylor \& Francis (Routledge). 